\title{
Forced decadal changes in the East Asian summer monsoon: the roles of greenhouse gases and anthropogenic aerosols
}

\author{
Fangxing Tian ${ }^{1}\left(\mathbb{D} \cdot\right.$ Buwen Dong $^{1} \cdot$ Jon Robson $^{1} \cdot$ Rowan Sutton $^{1}$
}

Received: 15 June 2017 / Accepted: 19 January 2018 / Published online: 13 February 2018

(c) The Author(s) 2018. This article is an open access publication

\begin{abstract}
Since the mid-1990s precipitation trends over eastern China display a dipole pattern, characterized by positive anomalies in the south and negative anomalies in the north, named as the Southern-Flood-Northern-Drought (SFND) pattern. This work investigates the drivers of decadal changes of the East Asian summer monsoon (EASM), and the dynamical mechanisms involved, by using a coupled climate model (specifically an atmospheric general circulation model coupled to an ocean mixed layer model) forced by changes in (1) anthropogenic greenhouse gases (GHG), (2) anthropogenic aerosol (AA) and (3) the combined effects of both GHG and AA (All Forcing) between two periods across the mid-1990s. The model experiment forced by changes in All Forcing shows a dipole pattern of response in precipitation over China that is similar to the observed SFND pattern across the mid-1990s, which suggests that anthropogenic forcing changes played an important role in the observed decadal changes. Furthermore, the experiments with separate forcings indicate that GHG and AA forcing dominate different parts of the SFND pattern. In particular, changes in GHG increase precipitation over southern China, whilst changes in AA dominate in the drought conditions over northern China. Increases in GHG cause increased moisture transport convergence over eastern China, which leads to increased precipitation. The AA forcing changes weaken the EASM, which lead to divergent wind anomalies over northern China and reduced precipitation.
\end{abstract}

\section{Introduction}

Summer precipitation over East Asia is mainly associated with the East Asian summer monsoon (EASM). Since the mid-1990s, the EASM circulation has exhibited a weakening tendency, characterized by an increase in the sea level pressure (SLP) over East Asia and a weakening of the lowertropospheric southwesterly wind. Associated with the weakened EASM circulation is enhanced precipitation over the middle and lower reaches of the Yangtze River valley and over south China, and suppressed precipitation over northern China. This pattern of rainfall change is named the "Southern Flood Northern Drought" (SFND) pattern (i.e. Wang 2001; Ding et al. 2008, 2009, although, note the time-period used to define the SFND in this study is different due to the need to avoid volcanic eruptions).

Fangxing Tian

fangxing.tian@ reading.ac.uk

1 Department of Meteorology, National Centre for Atmospheric Science, University of Reading, Reading, UK
Since the changes in EASM and associated precipitation can be induced by anthropogenic forcing changes as well as by natural variability, many previous studies have considered the relative importance of natural and anthropogenic forcing changes (Shen et al. 2008; Wang et al. 2012, 2013; Song et al. 2014). Some studies suggest that external forcing, such as the changes in greenhouse gas (GHG) concentrations and anthropogenic aerosol (AA) emissions, are the most important factors for generating the SFND pattern (Chen and Sun 2017; Ma et al. 2017; Wang et al. 2013; Xie et al. 2016; Zhang et al. 2017). For example, based on the coupled general circulation model (CGCM) Bergen Climate Model (BGM), and by using multi-ensemble simulations, Wang et al. (2013) argued that the SFND pattern is predominantly forced by the combined effect of increasing GHG and aerosol emissions.

In response to the increase in GHG concentration the climate system warms, because the atmosphere traps more outgoing longwave radiation and enhances the tropospheric radiative warming. Theories and numerical studies suggest that the warming caused by the increased GHG concentrations can change the atmospheric circulation by increasing the lower-tropospheric water vapor (Vecchi and Soden 2007; 
Held and Soden 2006). In response to the enhanced conditional instability caused by the increased moisture and warm sea-surface temperature (SST), the monsoon rainfall over the Western North Pacific Summer Monsoon (WNPSM) region increases (Lee et al. 2008). The Asian summer monsoon precipitation is also projected to enhance under greenhouse warming (Wang et al. 2014; Li et al. 2015; Li and Ting 2017).

Anthropogenic aerosols (AA) in the atmosphere can scatter and absorb the solar radiation directly, but also alter the radiative properties of clouds through aerosol-cloud interactions. The absorption of solar radiation leads to a significant heating of the troposphere. Both scattering and absorption cause surface cooling. Due to the heterogeneous aerosol distribution, the efficiency of the top of the atmosphere direct forcing of anthropogenic aerosols in causing climatological surface temperature change clearly differs from the uniformly distributed and long-lasting greenhouse gases (Penner et al. 2001; Wang 2004). The spatial heterogeneity can cause large changes of precipitation in the tropics where the circulation is known to be sensitive to horizontal temperature gradients, which is known as the dynamic effect of aerosol forcing (Ming and Ramaswamy 2011; Rotstayn and Lohmann 2002). This dynamic effect can be described as the southward shift of the intertropical convergence zone (ITCZ) in response to the heterogeneous aerosol emissions that are larger in northern hemisphere than in southern hemisphere (Rotstayn and Penner 2001; Williams et al. 2001; Wang 2006). Changes in AA emissions can also affect precipitation by directly altering the EASM system. Dong et al. (2016) suggested that the increase of both local aerosol emissions and remote emissions over Europe have likely contributed to the observed weakening of the EASM.

These previous studies have demonstrated that external forcing influences precipitation over East Asia, and suggest that changes in both GHG and aerosol emissions play important roles in decadal changes of the EASM. However, the relative individual contributions of changes in GHG and AA emission in generating the SFND pattern, and the exact processes that lead to the changes, are still not clear. Therefore, this work aims to quantify the relative roles of changes in GHG and AA forcing in shaping the SFND pattern and to understand the physical processes responsible.

Up to now, most of the attribution studies are based on Coupled General Circulation Models (CGCMs), i.e., model simulations that use constant emissions to force the CGCMs and reach equilibrium after a long integration (Bollasina et al. 2011; Li and Ting 2017; Wang et al. 2012, 2013). In CGCMs that include full ocean dynamics, the computational cost of such experiments is considerable. The CGCMs also exhibit significant biases in the mean state. For example, many CGCMs have a large cold equatorial SST bias in Pacific (Vanniere et al. 2013). Ocean thermodynamics, rather than dynamics, causes the majority of subseasonal tropical upper ocean variability (e.g., Waliser et al. 2004). Thus, replacing the 3D ocean GCM with an ocean mixedlayer model would reduce the cost of the experiments, and have a smaller SST bias (due to a prescribed flux correction), whilst also retaining intraseasonal variability and coupling between the atmosphere and the ocean. Therefore, this work is based on a set of experiments using a near-globally coupled atmosphere-ocean-mixed-layer model, MetUMGOML1 (Klingaman et al. 2011; Hirons et al. 2015).

The structure of this paper is as follows: Sect. 2 describes the observed changes in precipitation since the mid-1990s; Sect. 3 describes the model and experiments; Sect. 4 evaluates model responses to changes in anthropogenic forcing; Sect. 5 elucidates the physical processes involved in these responses and Sect. 6 is devoted to understanding the responses in large scale circulations. Finally, the main conclusions are summarized in Sect. 7.

\section{Observed changes in precipitation}

To show the decadal variability in summer (JJA) precipitation in the observations, we define indices of summer precipitation averaged over northern China $\left(105^{\circ} \mathrm{E}-20^{\circ} \mathrm{E}\right.$, $\left.32^{\circ} \mathrm{N}-2^{\circ} \mathrm{N}\right)$ and southern China $\left(110^{\circ} \mathrm{E}-20^{\circ} \mathrm{E}, 20^{\circ} \mathrm{N}-0^{\circ} \mathrm{N}\right)$. Figure 1a shows that over southern China, the mean precipitation is around $6.5 \mathrm{~mm} /$ day during the early period (EP, 1964-1981), which increased to $7.5 \mathrm{~mm} /$ day during the present day (PD, 1994-2011). Over northern China, the EPmean precipitation is around $2.5 \mathrm{~mm} /$ day and it is reduced to $2.2 \mathrm{~mm}$ /day during the $\mathrm{PD}$. The $\mathrm{PD}$ mean precipitation over southern China is $0.62 \mathrm{~mm} /$ day more than the longterm mean for the period 1950-2012, and $0.16 \mathrm{~mm} /$ day less over northern China than the long term mean. The difference between PD values and the long-term mean in both regions is statistically significant at the $10 \%$ level based on a twotailed Student's t-test.

To understand the mechanisms underlying the significant decadal variability in precipitation, we compare the spatial changes of lower tropospheric circulation and precipitation during the PD relative to those of the EP. As shown in Fig. 1b, the changes of circulation are characterized as anomalous northeasterly wind over the eastern China, indicating a weakening of the East Asian summer monsoon (EASM). Additionally, there is a cyclonic anomaly in southern China (blue box), indicating stronger convection. Associated with the weakening of the EASM, the main rain belt shifts southward (Ding et al. 2008, 2009). As shown in Fig. 1c, in northern China (red box), precipitation decreased by up to $0.25-0.5 \mathrm{~mm}$ /day and in southern China (blue box), it increased by around 


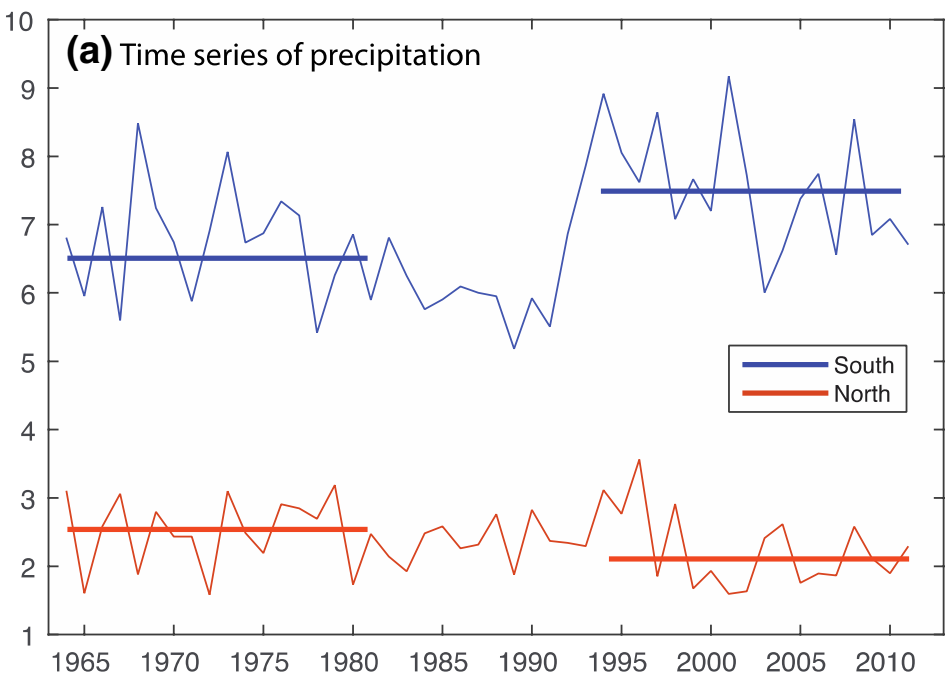

(b) SLP (Hads/p2r) and wind change in JJA (NCEP)

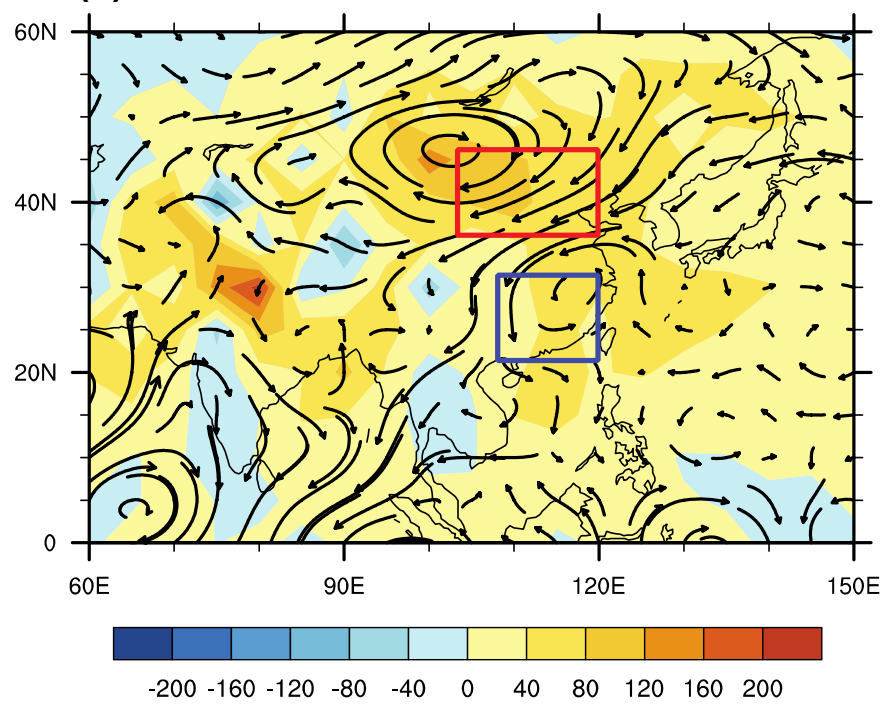

Fig. 1 a Time series of precipitation (mm/day) based on CRUTS3.21 data set over south China (blue) and north China (orange), blue and orange range bars indicate the time mean precipitation $(\mathrm{mm} /$ day) during the early period (1964-1981) and present day (1994-2011) b changes of SLP (Pa, HadSLP2r) and wind at $700 \mathrm{hPa}(\mathrm{m} / \mathrm{s})$ of NCEP

$0.5-1.5 \mathrm{~mm} /$ day. This pattern is named as the SouthernFlood-Northern-Drought (SFND) pattern across the mid-1990s.

To understand the drivers of the SFND pattern, and the dynamical mechanisms involved, we perform experiments with an atmosphere-ocean-mixed-layer model with changes in only GHG, and only AA, alongside an all forced experiment, as described below. (c) Precipitation changes in JJA (CRUTS3.21)

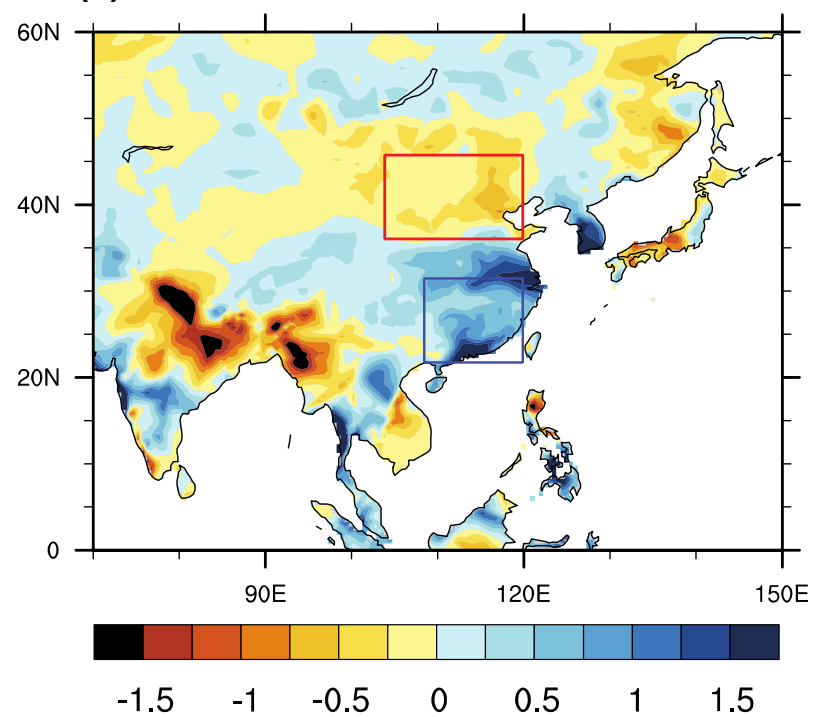

reanalysis between PD (1994-2011) and EP (1964-1981) in JJA and c precipitation (mm/day) changes between PD (1994-2011) and EP (1964-1981) in JJA. Box indicates selected region of south flood and north drought

\section{Model and experiments}

\subsection{Model}

This work uses the model MetUM-GOML1 (Hirons et al. 2015): a near-globally-coupled atmosphere-ocean-mixedlayer model. The atmospheric component is the Met Office 
Unified Model (MetUM) at the fixed scientific configuration Global Atmosphere 3.0 (GA3.0; Arribas et al. 2011; Walters et al. 2011). The resolution in current study is $1.875^{\circ}$ longitude and $1.25^{\circ}$ latitude (N96) with 85 vertical layers, the model lid is at $85 \mathrm{~km}$. The model includes earth system components such as an interactive tropospheric aerosol scheme which includes the following aerosol: ammonium sulphate, mineral dust, sea salt, fossil fuel black carbon, fossil fuel organic carbon, biomass burning aerosols, and secondary organic (biogenic) aerosols. The direct radiative effect due to scattering and absorption of radiation by all aerosol species is represented in the model. The semi-direct effect, whereby aerosol absorption tends to change cloud formation by warming the aerosol layer, is included implicitly (Walters et al. 2011). The parameterization of the indirect effects is described in detail by Jones et al. (2011).

The oceanic component is a Multi-Column K Profile Parameterization (MC-KPP) mixed-layer ocean model. MC-KPP is run as a two-dimensional matrix of 1-D water columns, with one column below each AGCM grid point that is wholly or partially ocean. Therefore, the horizontal resolution of MC-KPP is the same as the MetUM where it is coupled. In this study, MC-KPP is configured with a depth of $1000 \mathrm{~m}$ over 100 vertical levels. The vertical discretization of the MC-KPP columns is defined using a stretch function, allowing very high resolution in the upper ocean.
The vertical resolution is $1.2 \mathrm{~m}$ at the surface, and less than $2 \mathrm{~m}$ over the first $41.5 \mathrm{~m}$. Vertical mixing in MC-KPP is parameterized using the KPP scheme of Large et al. (1994). Since the mixed-layer model (MC-KPP) does not include ocean dynamics, a seasonally varying 3D flux corrections is applied to both temperature and salinity. The seasonally varying 3D temperature and salinity flux corrections are prescribed to represent the mean ocean advection and account for biases in atmospheric surface heat and freshwater fluxes.

The oceanic and atmospheric components are coupled via the Ocean Atmosphere Sea Ice Soil (OASIS) (Valcke et al. 2003) coupler. The coupling frequency between atmospheric and oceanic components is once every $3 \mathrm{~h}$.

\subsection{Experiments}

The experiments performed in this study are summarized in Table 1. With MetUM-GOML1, we first performed a relaxation experiment (R0) for 12 years, in which the temperature and salinity of the ocean (MC-KPP) are relaxed to a present day (PD, 1994-2011) climatology derived from the Met Office ocean analysis (Smith and Murphy 2007). The relaxation experiment uses PD anthropogenic greenhouse gas (GHG) and anthropogenic aerosol (AA) forcing (Lamarque et al. 2010, 2011), but otherwise the atmosphere is not constrained.

Table 1 Summary of numerical experiments

\begin{tabular}{|c|c|c|c|}
\hline Experiment & Ocean & Radiative Forcing & Abv \\
\hline \multicolumn{4}{|l|}{ Coupled run } \\
\hline Relaxation run & $\begin{array}{l}\text { Relax to PD mean 3D ocean temperature and salinity } \\
\text { to diagnose climatological temperature and salinity } \\
\text { flux corrections }\end{array}$ & $\begin{array}{l}\text { Climatological PD greenhouse gases (GHG) over PD } \\
\text { and anthropogenic aerosol (AA) precursor emis- } \\
\text { sions over PD with GHG and AA after } 2006 \text { from } \\
\text { RCP4.5 scenario (Lamarque et al. 2010, 2011) }\end{array}$ & R0 \\
\hline Coupled EP experiment & $\begin{array}{l}\text { Climatological temperature and salinity flux correc- } \\
\text { tions from relaxation run }\end{array}$ & $\begin{array}{l}\text { Climatological EP GHG and time mean EP AA } \\
\text { precursor emissions }\end{array}$ & $\mathrm{EP}$ \\
\hline \multirow[t]{3}{*}{ Coupled PD experiment } & $\begin{array}{l}\text { Climatological temperature and salinity flux correc- } \\
\text { tions from relaxation run }\end{array}$ & $\begin{array}{l}\text { Climatological PD GHG and PD AA precursor } \\
\text { emissions }\end{array}$ & PDGA \\
\hline & & $\begin{array}{l}\text { Climatological PD GHG and EP AA precursor emis- } \\
\text { sions }\end{array}$ & PDG \\
\hline & & $\begin{array}{l}\text { Climatological EP GHG and PD AA precursor emis- } \\
\text { sions }\end{array}$ & PDA \\
\hline \multicolumn{4}{|l|}{ AGCM run } \\
\hline AGCM EP experiment & $\begin{array}{l}\text { Prescribed daily sea surface temperature from EP } \\
\text { experiment }\end{array}$ & $\begin{array}{l}\text { Climatological EP GHG and EP AA precursor emis- } \\
\text { sions }\end{array}$ & AEP \\
\hline AGCM SST & $\begin{array}{l}\text { Prescribed daily sea surface temperature from EP } \\
\text { experiment + climatological daily SST anomalies } \\
\text { induced by changes in AA emissions in the coupled } \\
\text { responses (PDA-EP) }\end{array}$ & $\begin{array}{l}\text { Climatological EP GHG and EP AA precursor emis- } \\
\text { sions }\end{array}$ & ASST \\
\hline AGCM SST + AA & The same as in AGCM SST & $\begin{array}{l}\text { Climatological EP GHG and PD AA precursor emis- } \\
\text { sions }\end{array}$ & ASA \\
\hline
\end{tabular}

Early period (EP) indicates the period of 1964-1981 and present day (PD) indicates the period of 1994-2011. Note that a slightly different period of 1970-1981 for the aerosol forcing in the early period is used since aerosol emissions data before 1970 were not available 
The seasonal cycle of daily-mean 3D ocean temperature and salinity flux corrections are calculated from the coupled relaxation experiment (i.e. they are the average corrections that are need to maintain the climatological state). These 3D flux corrections are then imposed in the free-running coupled experiments (i.e. the free-running coupled experiments include no temperature or salinity relaxation to climatology). Although the flux corrections are designed to represent a background climatology, the use of flux corrections ensures that the temperature and salinity are not fixed and so they will respond to changes in external forcing (either GHG or AA). Therefore, the response of the EASM to a change in a particular forcing in the free-running experiments includes both the direct impact of the forcing (i.e. through land surface and atmosphere processes) and the indirect impact, which is mediated through the forcing induced SST change. The experiments represent the early period (1964-1981; EP), All Forcing present-day (1994-2011; PDGA), GHG forcing (PDG) and AA forcing (PDA). All experiments are run for 50 years and use the climatological PD sea ice extent from HadISST (Rayner et al. 2003). The last 45 years of each experiment are used for analysis (Table 1).

The response to a particular forcing is estimated by the mean difference between a pair of experiments that include and exclude that forcing. The combined effect of changes in both GHG and AA (hereafter All Forcing) is the difference between PDGA and EP experiment (PDGA-EP). The impact of change in GHG (hereafter GHG forcing) is the difference between PDG and EP (PDG-EP) and the impact of change in AA emission (hereafter AA forcing) is the difference between PDA and EP (PDA-EP). Statistical significance of the mean changes in model experiments is assessed using a two tailed Student t-test.

Additionally, three atmosphere-only experiments have been performed to understand the relative roles of the direct impact of AA changes relative to the AA induced SST changes on the EASM and the circulation changes in Pacific in coupled simulations. Each AGCM experiment is 32 years long, with the last 30 years used for the analysis. The first experiment is the CONTROL run, which is an AGCM run for early period (AEP). The second experiment (ASST) is as AEP, but with the SST anomaly computed by differencing the PDA and EP experiments added to the SST in the APE experiment. The third experiment (ASA) is as ASST, but with PD aerosols. All AGCM experiments use climatological PD sea ice extent from HadISST (Rayner et al. 2003).

The anomaly ASST-AEP is the impact of AA induced SST change and the anomaly ASA-ASST is the direct impact of AA change. The anomaly ASA-AEP is the response to the combined effect of the direct impact of AA change and the AA induced SST change in the AGCM experiment. If air-sea interactions are not important, then the anomaly ASA-AEP shall be very close to AA impact in the coupled simulation.

\section{The southern flood and northern drought pattern in model experiments}

\subsection{Model mean climatology}

The SSTs simulated in PD are compared with observations by Dong et al. (2017), which shows that the biases of simulated present day SST in MetUM-GOML1 are much smaller (typically between -0.5 and $0.5^{\circ} \mathrm{C}$ ) than those in CMIP5 models. The large scale patterns of observed SST differences between PD and EP are also well captured in MetUM-GOML1.

Figure 2 shows the comparison of the climatological features of the EASM in the PDGA experiment with the observed features. Figure 2a, c shows the spatial patterns of 700-hPa wind, SLP and climatological precipitation in observations respectively. The main feature of note is the subtropical anticyclone over the Western North Pacific that causes a southwesterly wind from the Indian Ocean and an easterly wind from the tropical Pacific to converge in the monsoon trough (green line) and become a strong southerly (Fig. 2a). The southerly wind transports moisture to East Asia and is related to the strong precipitation there (Fig. 2c). Figure 2c also shows that the precipitation in China decreases with latitude. The mean precipitation is more than $6 \mathrm{~mm} /$ day south of $30^{\circ} \mathrm{N}$, but less than $2 \mathrm{~mm} /$ day north of $35^{\circ} \mathrm{N}$.

The general features of the climatological summer precipitation, SLP and wind in observations are well reproduced by MetUM-GOML1 (Fig. 2b, d). However, the precipitation is overestimated over northern India and eastern China, which may be related to the simulated monsoon trough. In particular, the model overestimates the westerly wind over the Indian Ocean and the westerly winds extend too far to the east and into the Pacific, making the simulated monsoon trough deeper than observed, and the southerly from the South China Sea (SCS) is weaker.

In general, despite some deficiencies, the simulated precipitation and lower tropospheric circulation over East Asia compares fairly well with observations, which suggests that this model is an appropriate tool to study the response of regional precipitation to different forcings.

\subsection{Model simulated changes}

The simulated summer-mean changes of SLP, 700-hPa wind and precipitation in response to changes in All Forcing (both GHG and AA) are illustrated in Fig. 3. The changes in All Forcing cause increased SLP over northern India, and lead to easterly anomalies, indicating a weaker westerly wind from the Indian Ocean (Fig. 3a). The 


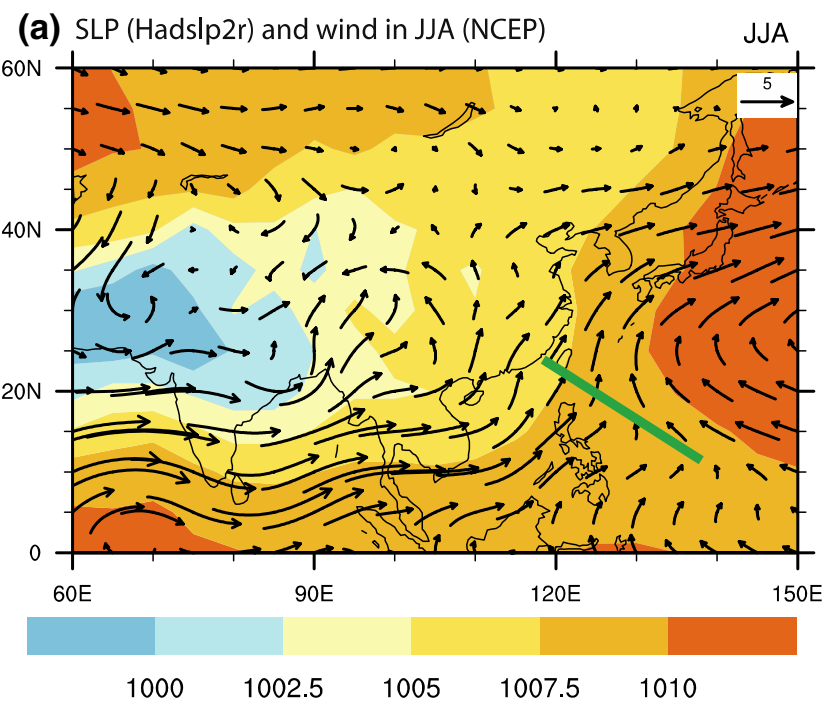

(c) Precipitation in JJA (CRUTS3.21)

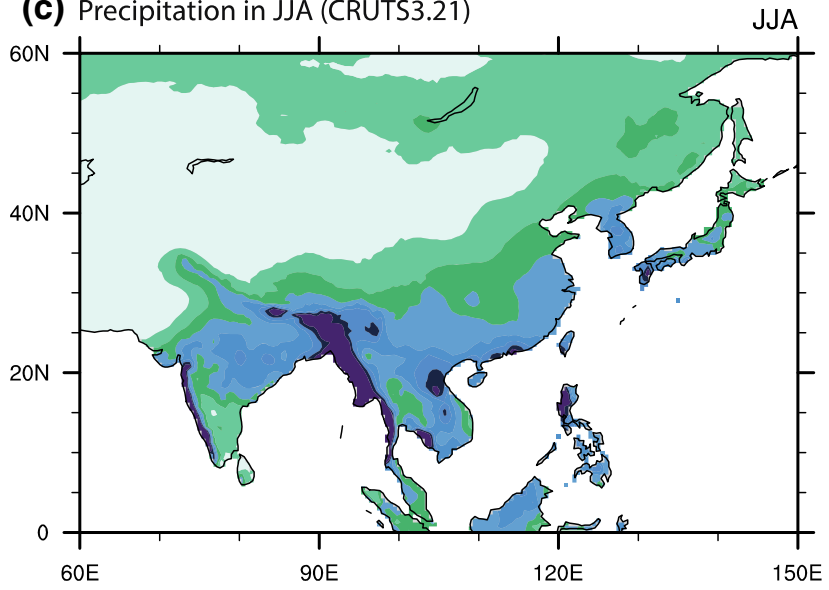

(b) SLP and wind in JJA (MetUM-GOML1)

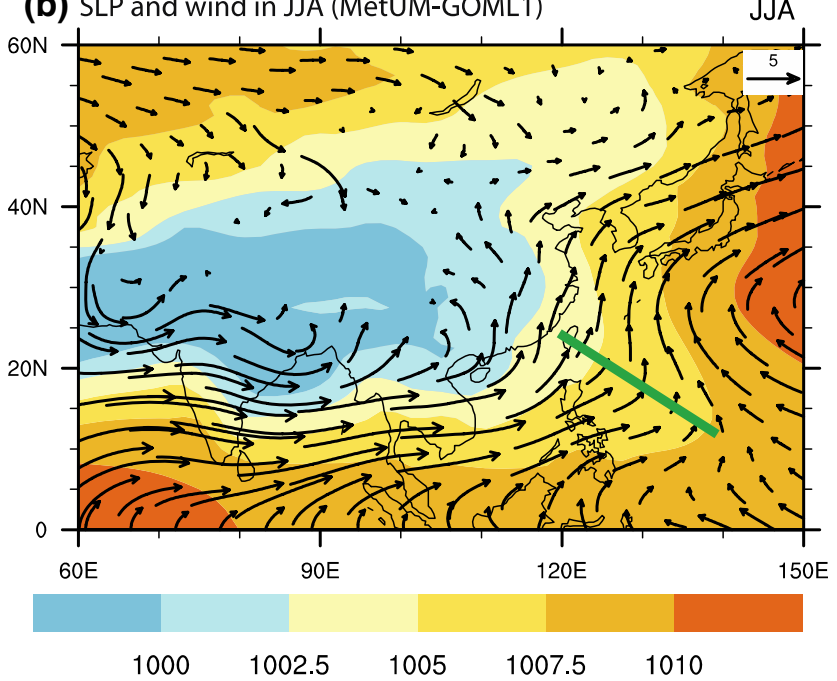

(d) Precipitation in JJA (MetUM-GOML1)

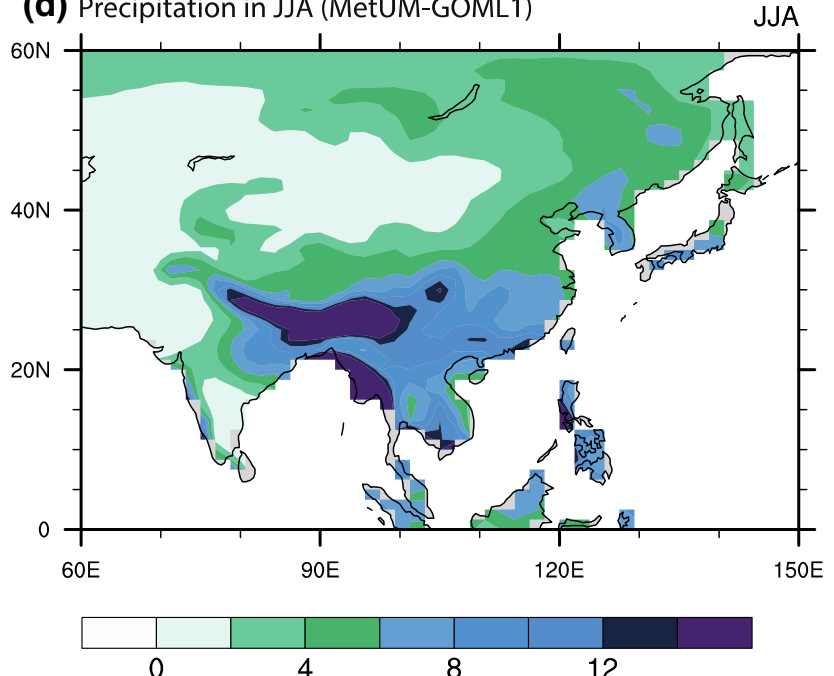

Fig. 2 a, b Climate state of present day (1994-2011) SLP (Pa) and $700 \mathrm{hPa}$ wind (m/s) in observations and model. c, d Climate state of present day precipitation (mm/day) (1994-2011) in observation and model

changes in All Forcing also lead to the enhancement and westward extension of the Western North Pacific Subtropical High (WNPSH) and a decrease of SLP to the northwest of WNPSH. Corresponding to the changes of SLP, there are northerly wind anomalies over northern China around $\left(110^{\circ}-120^{\circ} \mathrm{E}, 40^{\circ}-50^{\circ} \mathrm{N}\right)$ and a cyclonic circulation anomaly over southern China $\left(105^{\circ}-125^{\circ} \mathrm{E}, 10^{\circ}-35^{\circ} \mathrm{N}\right)$.

The weaker westerly wind from Indian Ocean and the anomalous northeasterly wind over $\left(110^{\circ}-120^{\circ} \mathrm{E}, 30^{\circ}-50^{\circ} \mathrm{N}\right)$ are also seen in observations (Fig. 1b). However, in observations, the anomalous northeasterly wind over $\left(110^{\circ}-120^{\circ} \mathrm{E}\right.$, $\left.30^{\circ}-50^{\circ} \mathrm{N}\right)$ is due to an increase in SLP around $\left(45^{\circ} \mathrm{N}\right.$, $100^{\circ} \mathrm{E}$ ), which is not captured in the model simulation. The simulated northwesterly wind anomaly over $\left(110^{\circ}-120^{\circ} \mathrm{E}\right.$, $30^{\circ}-50^{\circ} \mathrm{N}$ ) is related to a decrease in SLP to the northwest of the WNPSH around $\left(110^{\circ}-130^{\circ} \mathrm{E}, 30^{\circ}-50^{\circ} \mathrm{N}\right)$. However, we found the relationship between the SFND and SLP over $\left(100^{\circ} \mathrm{E}-110^{\circ} \mathrm{E}, 40^{\circ} \mathrm{N}-50^{\circ} \mathrm{N}\right)$ in observations to be weak on decadal time-scales (not shown). For the decadal changes, anomalous high sea level pressure over $100^{\circ} \mathrm{E}-110^{\circ} \mathrm{E}$, $40^{\circ} \mathrm{N}-50^{\circ} \mathrm{N}$ contributes to surface warming in observations. While in the model simulated response, anomalous low pressure is the atmospheric response to the surface warming.

The simulated precipitation changes show a dipole pattern similar to the observed SFND pattern (Fig. 3b). There is increased precipitation over southern China, and decreased precipitation over northern China. The difference in both regions is statistically significant at the $10 \%$ level based on a two-tailed Student's t-test. While the simulated changes have a similar structure to those in observations, the precipitation increase over southern China is underestimated compared to observations (Fig. 1). The similarity between the simulated 


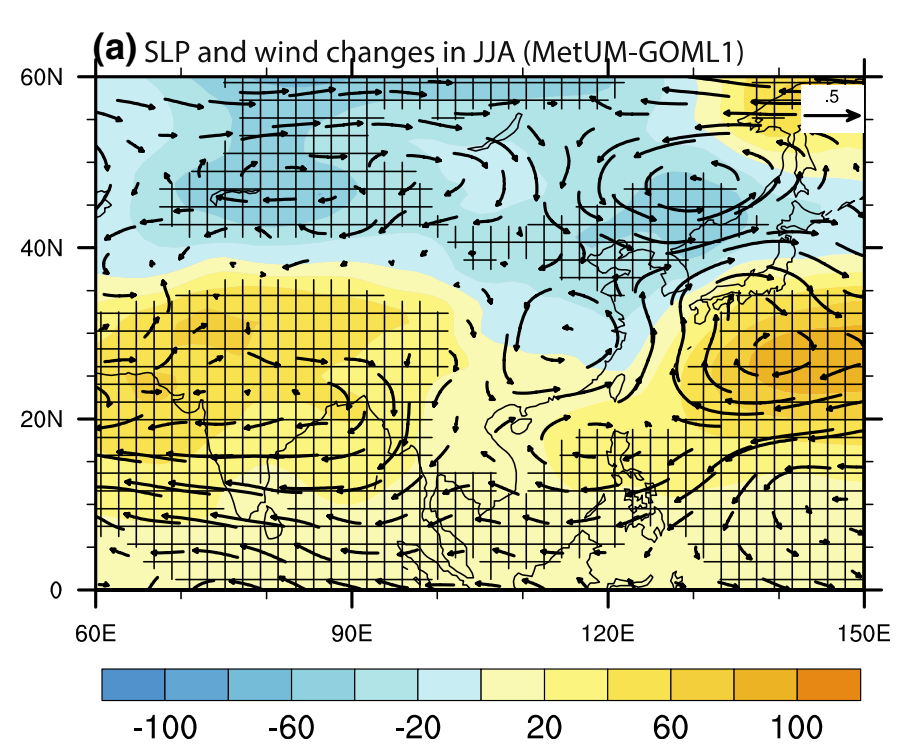

Fig. 3 Changes of a $700 \mathrm{hPa}$ wind (m/s) and SLP (Pa) b precipitation $(\mathrm{mm} /$ day) in JJA in response to All Forcing (PDGA-EP). Box indicates selected region of south flood and north drought, the same as in

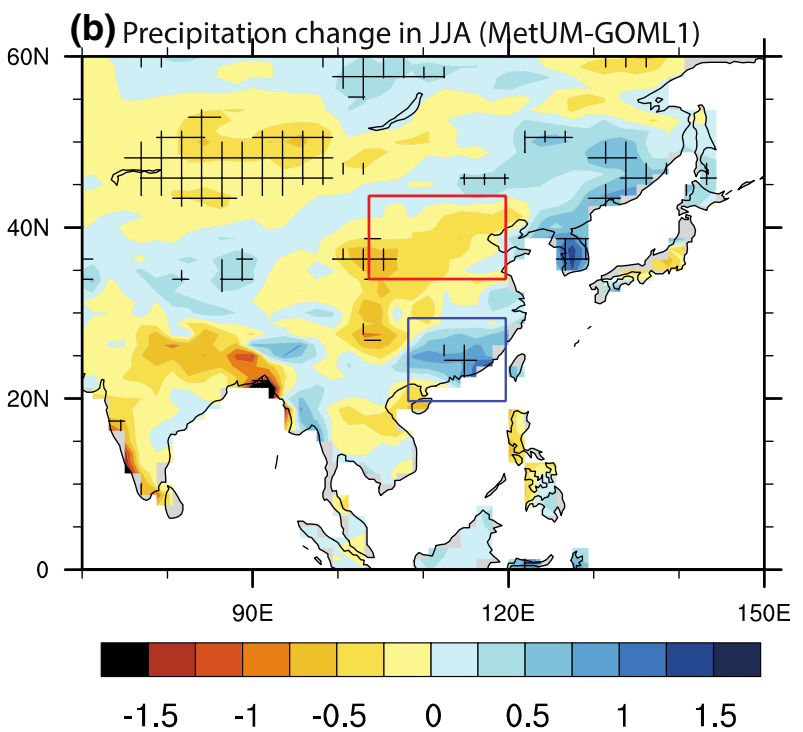

Fig. 1. Grids in b highlight regions where the changes are statistically significant at the $10 \%$ level using a two-tailed Student t-test

is significantly decreased over northern China (Fig. 4d). Precipitation is slightly increased over southern China (Fig. 4d), but the regional-averaged change is insignificant (Fig. 6a).

In summary, the simulated response to changes in All Forcing indicates changes in GHG and AA emissions play an important role in generating the SFND pattern. However, the responses changes in GHG and AA show some different characteristics. Model results indicate that GHG forcing tends to increase precipitation over eastern China, with a maximum over the southern China, and AA forcing is likely to reduce precipitation, especially over northern China.

\section{The processes related to the southern flood and northern drought pattern} ward from the South China Sea (SCS). Note the increase in precipitation is stronger over southern China (blue box) than over the northern China. The difference of regional mean precipitation is statistically significant at $10 \%$ level based on a two-tailed Student's t-test.

In response to changes in AA emissions, SLP rises over a large region north of $20^{\circ} \mathrm{N}$, especially over northern India and the Western North Pacific (Fig. 4b). The WNPSH is enhanced and displaced eastward with an anomalous southerly occurring over the Western North Pacific. The changes in SLP reduce the meridional pressure gradient, leading to a weakened westerly along $10^{\circ} \mathrm{N}$ from Indian Ocean. Additionally, anomalous northerly wind over eastern China $\left(100^{\circ}-110^{\circ} \mathrm{E}, 30^{\circ}-40^{\circ} \mathrm{N}\right)$ indicate a weakening water vapor transport from the South China Sea (SCS). Consistent with the weakening westerly wind from the Indian Ocean and southerly wind from the SCS, the precipitation
In order to explore the different processes that contribute to the precipitation changes, the column integrated moisture transport convergence has been analyzed. Furthermore, the moisture transport convergence is separated into components due to anomalous circulation and the part due to anomalous specific humidity in order to investigate the dynamic and thermodynamic effects ( $\mathrm{Li}$ and Ting 2017; Li et al. 2015; Trenberth and Guillemot 1995).

The changes of precipitation in Figs. $3 b$ and $4 c, d$ are compared with the moisture transport convergence in Fig. 5a-c. The similarity between changes in precipitation and changes in moisture transport convergence indicates that the changes of moisture transport convergence in response to changes in All Forcing, GHG forcing and AA forcing is predominantly responsible for the changes in precipitation. 
(a) GHG forced SLP and wind change in JJA

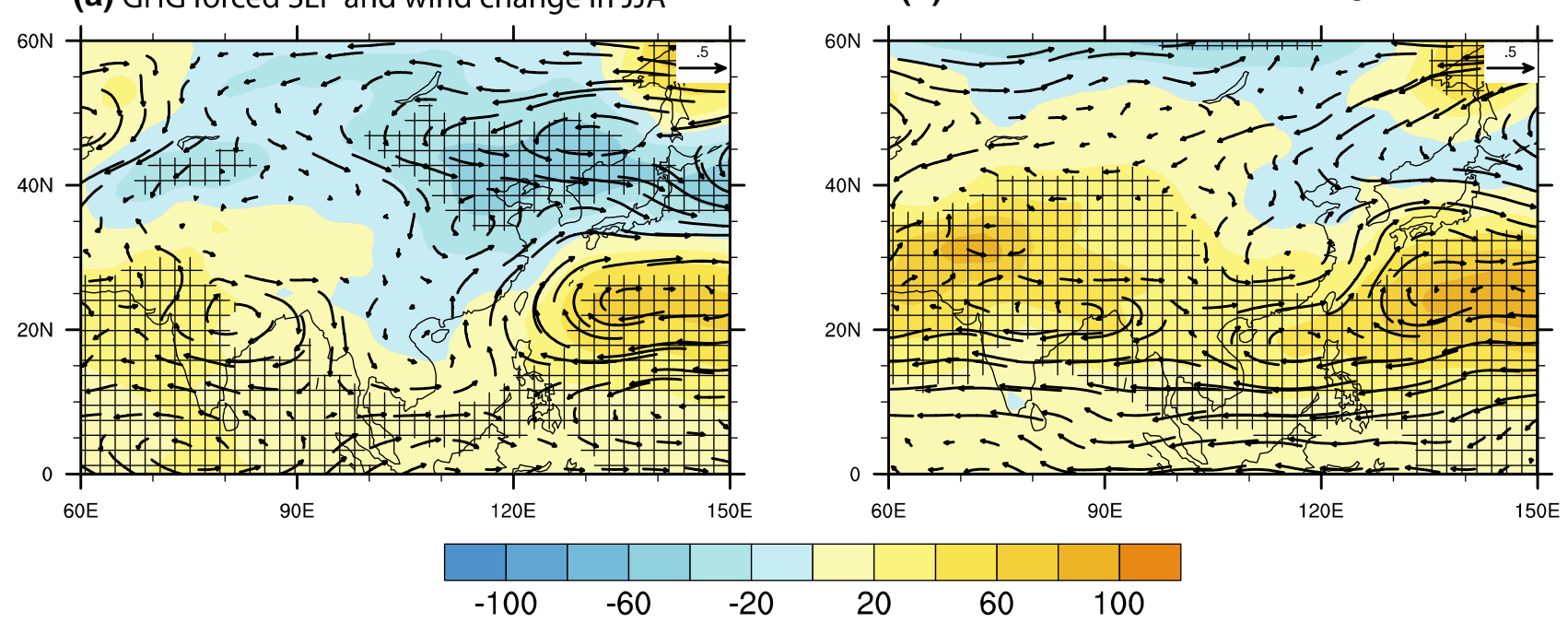

(b) AA forced SLP and wind change in JJA (c) GHG forced Precipitation change in JJA

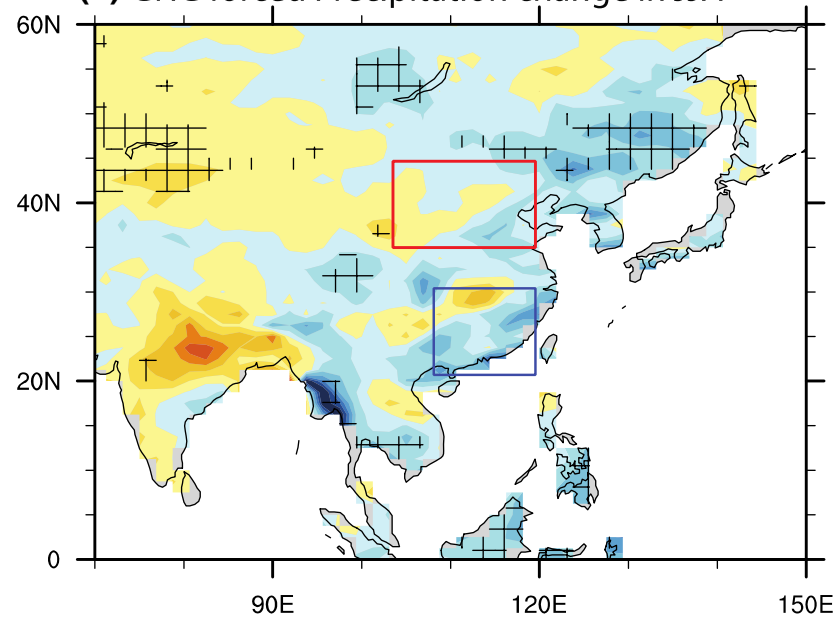

(d) AA forced Precipitation change in JJA

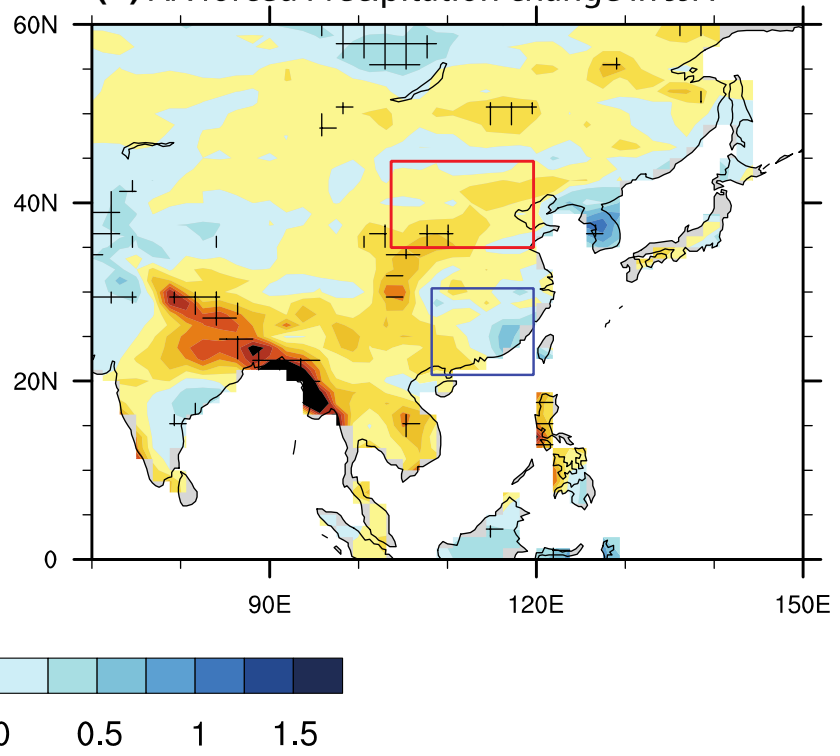

Fig. 4 Changes of $700 \mathrm{hPa}$ wind (m/s) and SLP (Pa) (a, b) and precipitation (c, d) between $\mathrm{PD}$ and EP experiments in JJA. a, c Response to GHG forcing (PDG-EP) and $\mathbf{b}$, $\mathbf{d}$ responses to AA forc- ing (PDA-EP). Box indicates selected region of south flood and north drought. Grids in $\mathbf{c}$ and $\mathbf{d}$ highlight regions where the changes are statistically significant at the $10 \%$ level using a two-tailed Student t-test
We then decompose the moisture transport convergence into the part due to changes in the dynamics (i.e. the dynamic effect, Fig. 5d-f) or the changes due to humidity changes (i.e. the thermodynamic effect, Fig. 5g-i). The decomposition shows that the spatial pattern and the magnitude of the moisture transport convergence change (Fig. 5a-c) is largely due to the dynamic effect (Fig. 5d-f). In response to changes in GHG forcing, the thermodynamic effect is also relatively large in south China (blue box). By comparison, the thermodynamic effect is relatively weak in response to AA forcing changes.
To quantify the relative roles of changes in GHG forcing and AA forcing in changes of the EASM and associated precipitation, we analyze the area-averaged precipitation, moisture transport convergence, and the dynamic and thermodynamic components of moisture transport convergence over the SFND areas highlighted in Fig. 5. Over southern China (Fig. 6a), the increase of precipitation caused by All Forcing (blue bar) is dominated by the increase of moisture transport convergence, which is mainly due to the dynamical effect. 


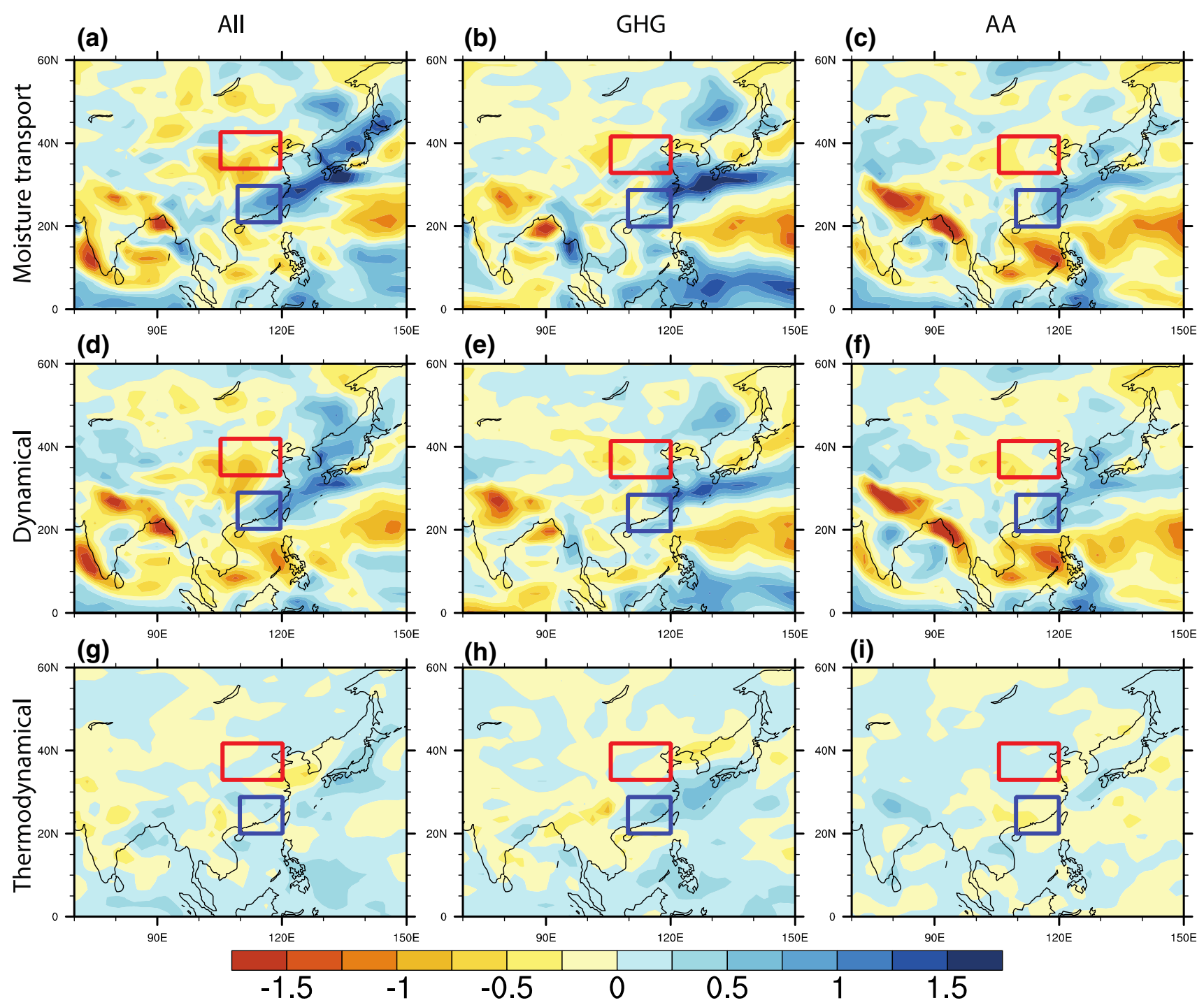

Fig. 5 a-c Differences of moisture transport convergence (mm/day) between PD and EP experiments in JJA for All Forcing, GHG forcing and AA forcing. d-f same as $\mathbf{a}-\mathbf{c}$ but the differences of dynamical effect. $\mathbf{g}-\mathbf{i}$ same as $\mathbf{a}-\mathbf{c}$ but the differences of thermodynamic effect

Isolating the roles of different forcings in the model indicates that the increase of precipitation in southern China is mainly due to GHG forcing (green bars), which explains up to $80 \%$ of the simulated precipitation change in response to All Forcing. The GHG forced precipitation increase is also dominated by the increase of the moisture transport convergence. Both dynamic and thermodynamic components increase the total moisture transport convergence due to GHG, but the thermodynamic effect is twice the magnitude of the dynamic effect. The importance of the thermodynamic effect is consistent with the increase in the precipitable water in the atmosphere due to GHG forced warming (see Fig. 7). Such a GHG effect agrees with the so called "rich get richer" mechanism (Chou et al. 2009): i.e., an increased moisture content in the atmosphere due to the warming leads to a greater moisture transport convergence that enhances precipitation over southern China. The enhanced precipitation in turn forces anomalous large-scale low-level convergent flow, which further strengthens the positive rainfall anomalies. In comparison with the GHG, the impact of changes in AA forcing (yellow bars) on precipitation in south China is relatively weak and not significant.

Over northern China (Fig. 6b), changes in All Forcing lead to a decrease of the area mean precipitation (blue bars). The decrease in precipitation is again dominated by changes of moisture transport convergence, which is mainly due to the dynamic effect. The thermodynamic component is small and insignificant. Considering the response of precipitation to different forcings, results show that the reduction in precipitation over northern China is mainly due to the effect of AA forcing, which determines the sign of the precipitation anomaly. The AA forced reduction of precipitation in 
Fig. 6 Area averaged precipitation ( $\mathrm{mm} /$ day), moisture transport convergence (MT, $\mathrm{mm} /$ day), dynamic effect (D, $\mathrm{mm} /$ day) and thermodynamic effect ( $\mathrm{T}, \mathrm{mm} /$ day) in a over south flood region $\left(110^{\circ} \mathrm{E}-120^{\circ} \mathrm{E}\right.$, $20^{\circ} \mathrm{N}-30^{\circ} \mathrm{N}$ ) and $\mathbf{b}$ over north drought region $\left(105^{\circ} \mathrm{E}-120^{\circ} \mathrm{E}\right.$, $32^{\circ} \mathrm{N}-42^{\circ} \mathrm{N}$ ) in response to All Forcing (blue), GHG forcing (green) and AA forcing (yellow). Error bars indicate the standard error of mean difference for a variable
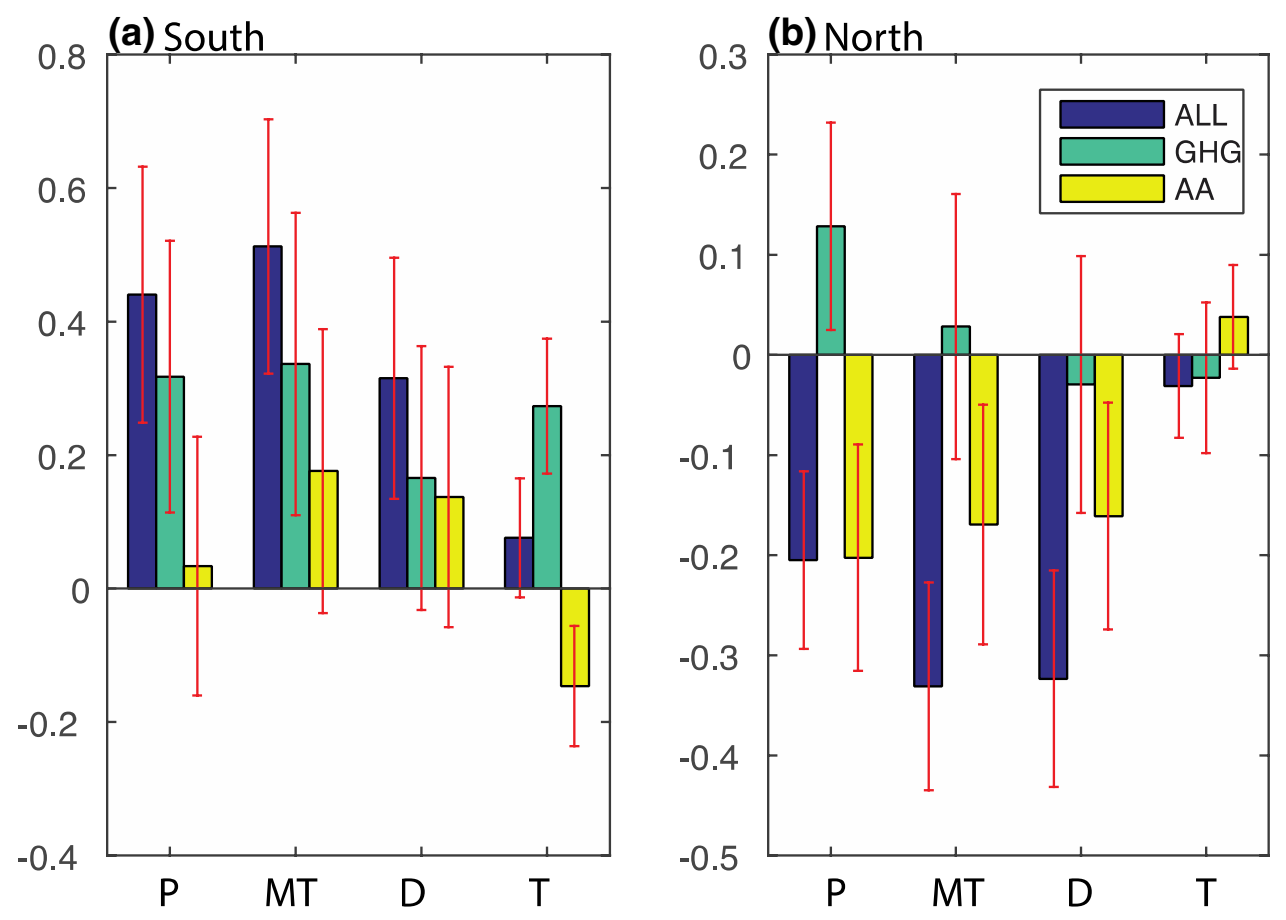

(a) All

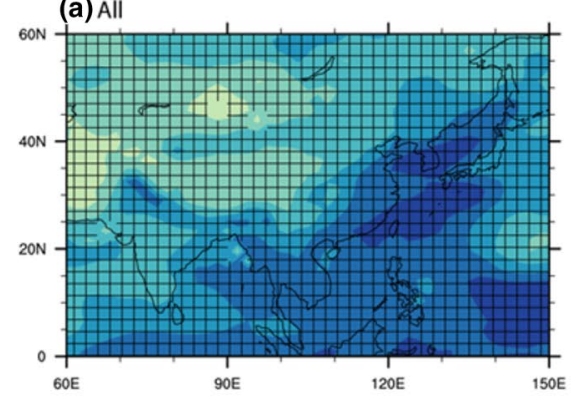

(b) GHG

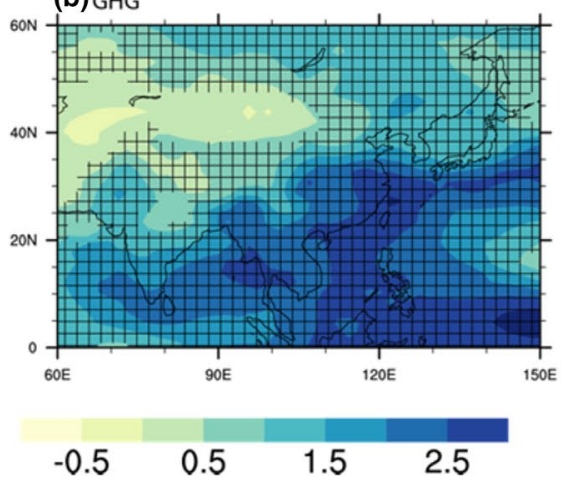

(c) $\mathrm{AA}$

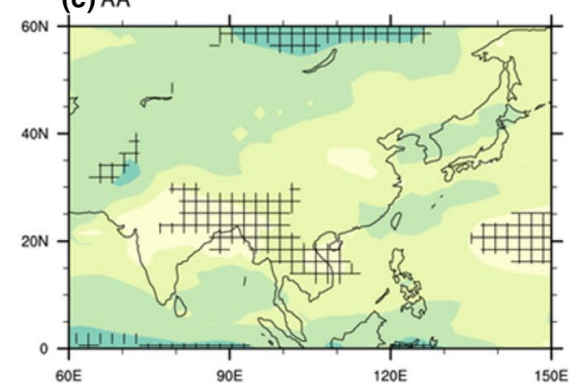

Fig. 7 Changes of precipitable water (mm) between PD and EP experiments in JJA in response to a All Forcing, b GHG forcing and $\mathbf{c}$ AA forcing. Dots highlight regions where the changes are statistically significant at the $10 \%$ level using a two-tailed Student t-test

northern China explains up to $95 \%$ of the simulated precipitation decrease in the All-Forcing experiment. Almost 80\% of the AA forced decrease in precipitation comes from the decrease of the moisture transport convergence, and it is dominated by the dynamic component.

The SFND precipitation pattern in the model experiments is dominated by the changes of the moisture transport convergence. Over southern China, the enhancement of the moisture transport convergence is mainly due to GHG forcing, which involves both the dynamic and thermodynamic components. Over northern China, the reduction of moisture transport convergence is dominated by the changes in AA forcing, through a weakening of the dynamic component of the moisture transport convergence.

\section{The changes of large scale circulation related to the SFND pattern}

In Sect. 5 we showed that GHG and AA changes make differing contributions to regionally averaged precipitation changes over China. In this section, we explore the large scale circulation responses to forcing, and determine how the responses to the individual forcings combine to produce the observed SFND pattern. 


\subsection{Changes in large scale circulation in response to changes in different forcings}

In the single forced experiments, one contrasting feature over East Asia is the opposing signs of SLP response to GHG and AA changes (Fig. 4a, b). In the GHG-forcing experiment, the anomalous low pressure over East Asia and the enhanced WNPSH leads to enhanced southerly winds along the east coast of China (Fig. 4a). These southerly winds transport more moisture from the SCS and, in turn, contributes to the increased precipitation over southern China (Fig. 4c). In contrast, SLP increases over East Asia and WNPSH in AA-forcing experiment (Fig. 4b). The anomalies SLP lead to weaker EASM and decreased precipitation over northern China. Since the changes in subtropical circulation are important for generating the SFND pattern, in this section we focus on understanding how the subtropical SLP and the related large scale circulation responds to changes in different forcings.

We first place the SLP changes in the global context in Fig. 8a-c. In response to changes in All Forcing (Fig. 8a), the SLP is generally raised at the subtropical latitudes $\left(20^{\circ} \mathrm{N}-30^{\circ} \mathrm{N}\right)$, with the maximum over East Asia and Western North Pacific. Over East Asia, the increase of SLP is related to the heterogeneous warming over land, which is much weaker over northern India $\left(20^{\circ} \mathrm{N}\right)$ than over mid-latitude regions $\left(30^{\circ} \mathrm{N}-50^{\circ} \mathrm{N}\right)$ (Fig. 8d). The changes of surface air temperature (SAT) correspond to the positive anomalies of the zonal-mean meridional stream function over East Asia $\left(90^{\circ} \mathrm{E}-120^{\circ} \mathrm{E}\right.$ ) between $10^{\circ} \mathrm{S}-10^{\circ} \mathrm{N}$ (colours in Fig. 9a) and sinking anomalies around $10^{\circ}-20^{\circ} \mathrm{N}$ (arrows in Fig. 9a), which increases the SLP over South Asia at $20^{\circ} \mathrm{N}$ (Fig. 8a).

Over the Western North Pacific, the increased WNPSH is associated with the heterogeneous SST warming (Fig. 8g), which has a local maximum in the equatorial Pacific and

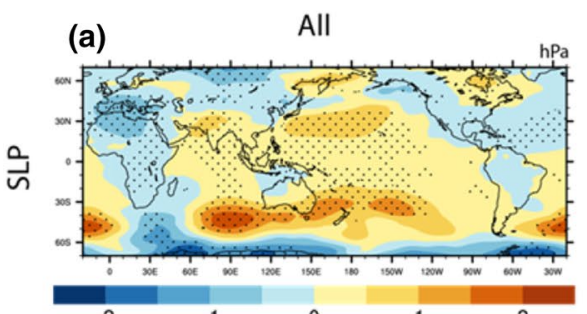

(d)
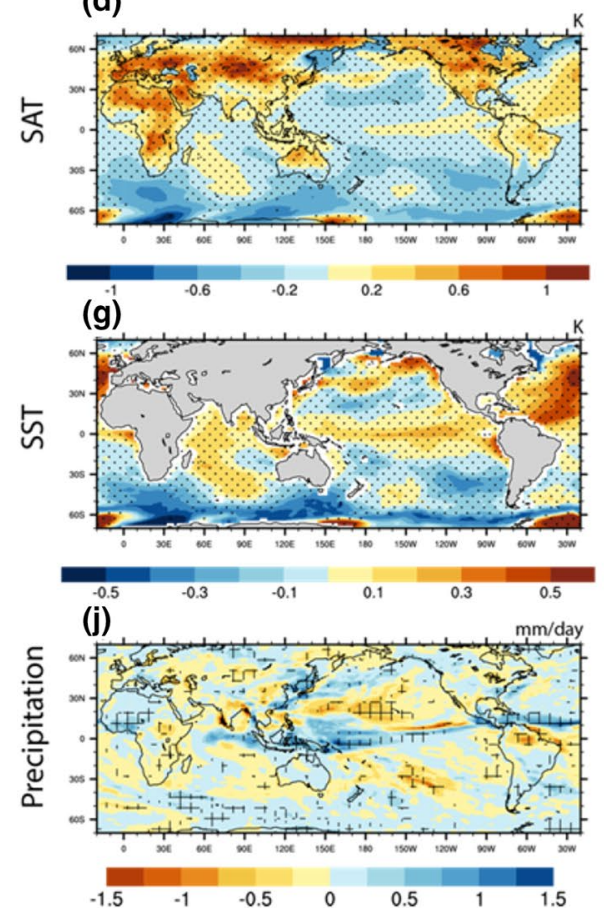

(b)

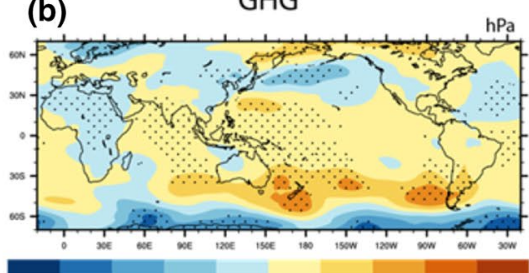

$\left(e^{-2}\right.$

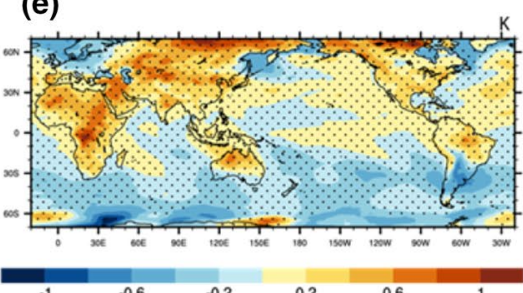

(h)
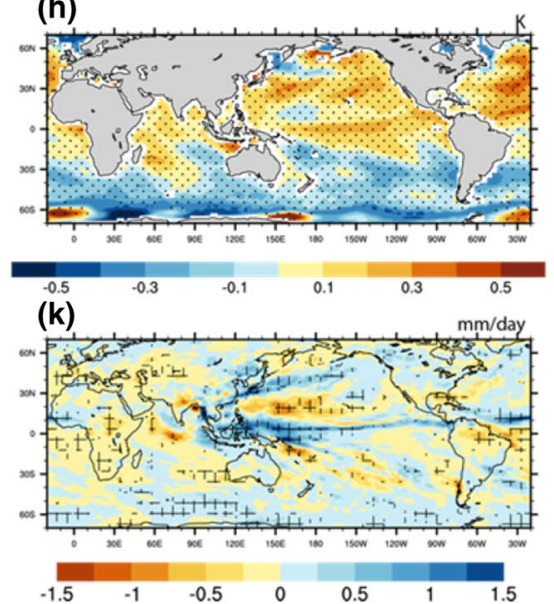

(c)

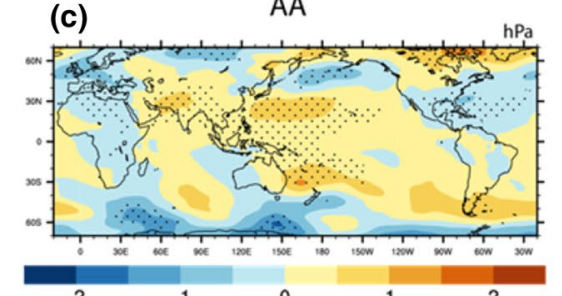

(f)

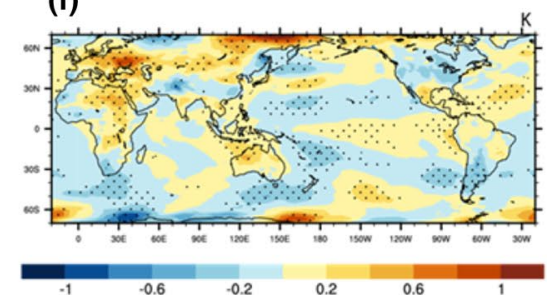

(i)
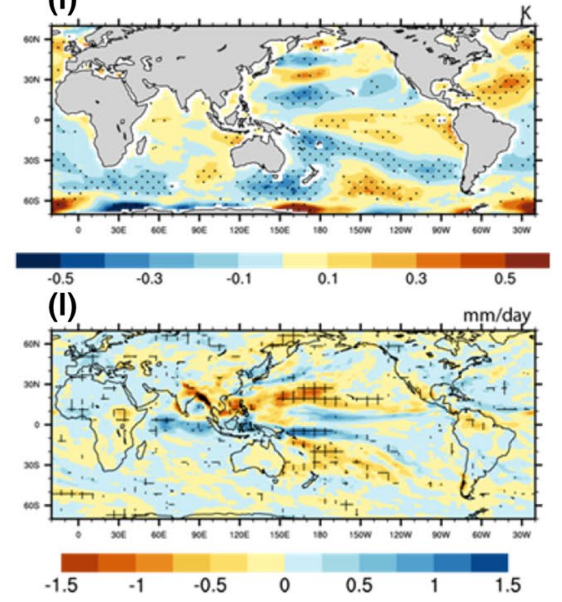

Fig. 8 SLP $(\mathbf{a}-\mathbf{c}$, hPa $)$, TAS $\left(\mathbf{d}-\mathbf{f},{ }^{\circ} \mathrm{C}\right)$, SST $\left(\mathbf{g}-\mathbf{i},{ }^{\circ} \mathrm{C}\right)$ and Precipitation ( $\mathbf{j}-\mathbf{l}, \mathbf{m m} /$ day) difference between PD and EP experiments in JJA in response to All Forcing (left column), GHG forcing (middle column) and AA forcing (right column). Change in $\mathbf{g - i}$ has the global mean SST anomalies removed. Grids and dots highlight regions where the changes are statistically significant at the $10 \%$ level using a two-tailed Student t-test 

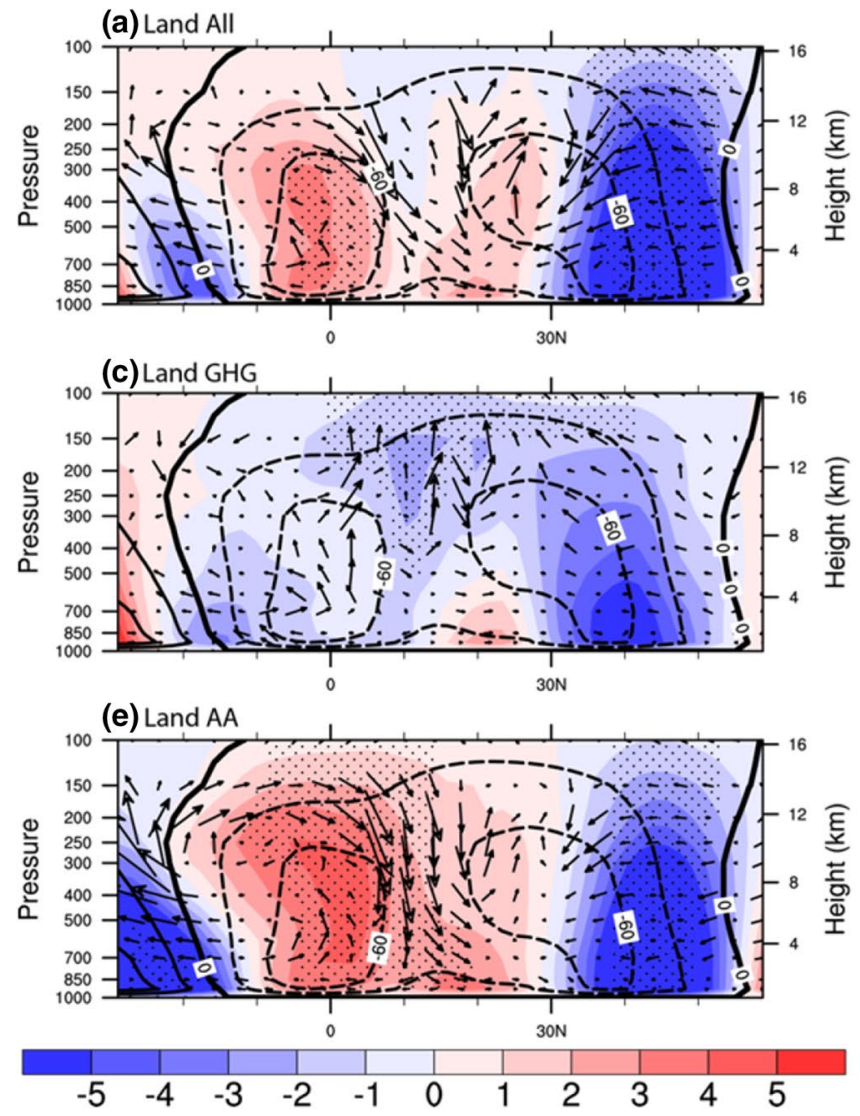

Fig. 9 Zonal mean meridional stream function $\left(\mathrm{kg} / \mathrm{s} \times 10^{10}\right)$ and wind anomalies $\left(\mathrm{m} / \mathrm{s} \times 10^{-3}\right)$, a, c, e over region $\left(30^{\circ} \mathrm{S}-60^{\circ} \mathrm{N}\right.$, $\left.90^{\circ} \mathrm{E}-120^{\circ} \mathrm{E}\right), \mathbf{b}, \mathbf{d}, \mathbf{f}$ over the Pacific $\left(30^{\circ} \mathrm{S}-60^{\circ} \mathrm{N}, 120^{\circ} \mathrm{E}-150^{\circ} \mathrm{W}\right)$. Dashed lines indicate the climate state of EP experiment. Colours are

minimum in the subtropical Pacific around $30^{\circ} \mathrm{N}$. The warm SST is associated with enhanced precipitation over the western equatorial Pacific (Fig. 8j), consistent with the sensitivity of tropical precipitation to modest SST warming (Xie et al. 2010). As stated in Dai et al. (2013), the latent heat release related to the enhanced precipitation warms the upper troposphere. As a result, the changes of SST and precipitation correspond to the positive cell of the zonal-mean meridional stream function over the west Pacific $\left(120^{\circ} \mathrm{E}-150^{\circ} \mathrm{W}\right)$ between $0^{\circ}-20^{\circ} \mathrm{N}$ (colours Fig. 9b) with anomalous rising over the equatorial Pacific (arrows in Fig. 9b) and anomalous sinking around $20^{\circ} \mathrm{N}$ (Fig. 9b), which enhances the WNPSH (Fig. 8a).

Analyzing the separately forced experiments we find that the positive anomalies of zonal-mean meridional stream function and the sinking anomaly over East Asia (Fig. 9a) is not simulated in GHG-forcing experiment (Fig. 9c). However, the sinking anomaly is reproduced in the AA-forcing experiment (Fig. 9e). In response to AA forcing, the SAT cools over northern India (Fig. 8f). This cooling is related to the positive cell of zonal-mean meridional stream function
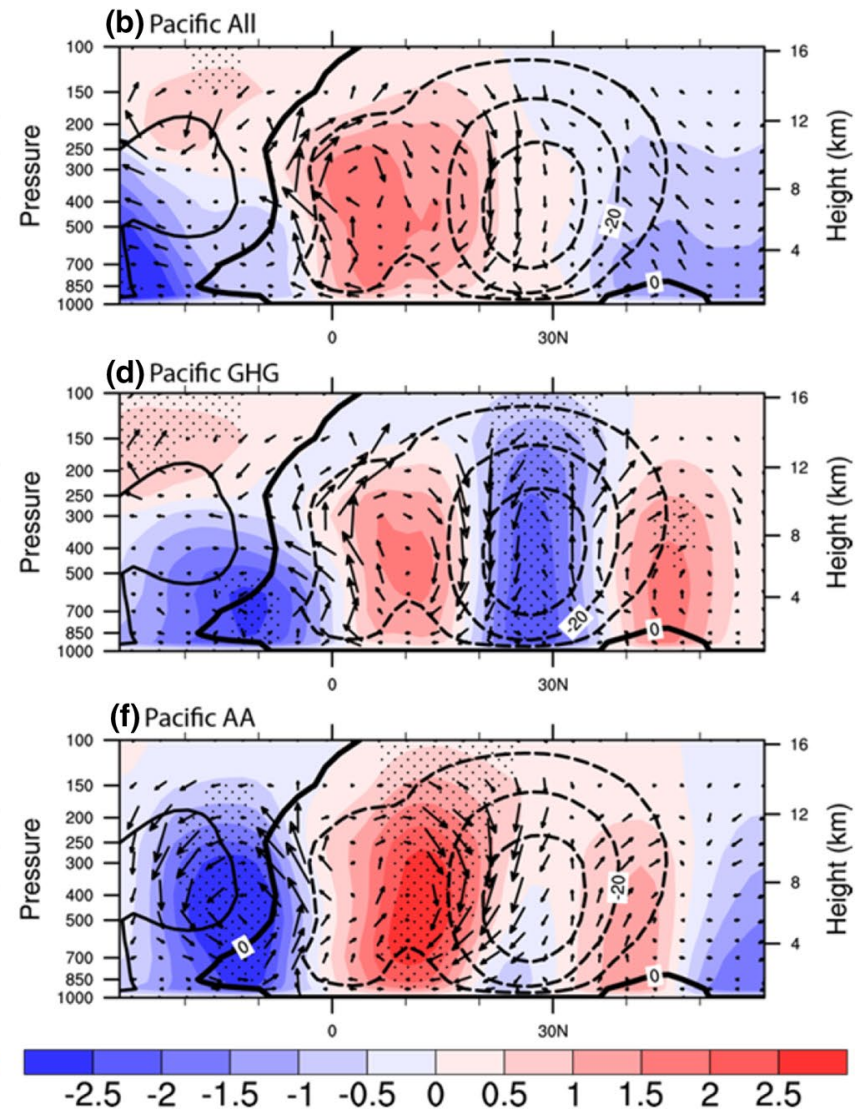

the anomalies in response to changes in a, b All Forcing c, d GHG forcing and e, $\mathbf{f}$ AA forcing. Dots highlight regions where the changes are statistically significant at the $10 \%$ level using a two-tailed Student t-test

between $10^{\circ} \mathrm{S}-10^{\circ} \mathrm{N}$ (Fig. 9e) and sinking anomaly between $10^{\circ} \mathrm{N}-20^{\circ} \mathrm{N}$ (arrows in Fig. 9e), which increases the SLP in East Asia (Fig. 8c). In contrast, in response to GHG forcing, the SAT warms strongly over Asian Continent (Fig. 8e), corresponding to negative anomalies of zonal-mean meridional stream function (Fig. 9c) and ascent in the northern Hemisphere (arrows in Fig. 9c), which reduces SLP over East Asia (Fig. 9b).

Although there is a contrast in the circulation response over East Asia between the separately forced experiments, the WNPSH is enhanced in both the GHG-forcing and AAforcing experiments (Fig. 8b, c). In GHG-forcing experiment (Fig. 8h), the Pacific SST warming has a minimum between $10^{\circ} \mathrm{N}-20^{\circ} \mathrm{N}$ and maximum near the equator. This corresponds to positive anomalies of the zonal-mean meridional stream function over the west Pacific between $0^{\circ}-15^{\circ} \mathrm{N}$ (Fig. 9c) with anomalous ascent over the equator and sinking anomaly around $20^{\circ} \mathrm{N}$ (Fig. 9d). In response to AA forcing, the SST cools over the subtropical north Pacific. The cool SST anomalies relate to more stable atmosphere over the subtropical Pacific and suppressed precipitation (Fig. 8i, 
1). The anomalous SST and precipitation correspond to the positive anomalies of zonal-mean meridional stream function over the west Pacific between $0^{\circ}-20^{\circ} \mathrm{N}$ (Fig. 9f) with anomalous ascent near the equator and sinking anomaly between $20^{\circ} \mathrm{N}-30^{\circ} \mathrm{N}$ (arrows in Fig. 9f). The sinking anomalies in both GHG- and AA-forcing experiments enhance the WNPSH (Fig. 8b, c).

The results above indicate that the enhanced WNPSH is a response to changes in both GHG forcing and AA forcing, and is the result of heterogeneous SST warming with a maximum in the equatorial western Pacific. The increased SLP over South Asia is mainly due to changes in AA forcing, and is consistent with the surface cooling over South Asia, which decreases the land sea thermal contrast.

\subsection{Understanding the enhancement of WNPSH}

The above analysis shows that the changes in the WNPSH are important to the SFND pattern, and that changes in the WNPSH are associated with the heterogeneous changes in Pacific SST. However, it is not clear whether the enhancement of WNPSH is the result of the fast response to the changes of GHG and AA forcing or the slow response to the changes of SST induced by GHG or AA forcing.

The relative roles of GHG induced SST anomalies and the direct impact of GHG radiative effect for changes in tropical precipitation are studied in many previous studies (Dong et al. 2009; Xie et al. 2010; Li and Ting 2017). These studies suggest that the GHG induced SST anomalies, in particular the equatorial maximum in SST warming over the Pacific, play a dominant role in changing tropospheric stability and tropical precipitation. However, further work is still needed to understand the changes in local Hadley circulation and subtropical SLP in response to changes in AA forcing. Thus, we performed another set of AGCM experiments to distinguish (1) the direct impact of AA changes (i.e. without allowing SST to change), (2) the impact of AA induced SST changes and (3) the combined impact (Table 1).

When forcing the AGCM by the change in AA emissions together with the anomalous SST induced by AA changes, the precipitation is suppressed over the subtropical North Pacific and the ITCZ is shifted southward (Fig. 10a). This pattern is similar to the response to changes in AA emissions in the coupled model as shown in Fig. 8i. We also find that the WNPSH is significantly enhanced (Fig. 10b). The suppressed convection and the southward shift of the ITCZ are associated with positive anomalies of stream function at latitudes between $0^{\circ} \mathrm{N}-30^{\circ} \mathrm{N}$ corresponding to anomalous ascent in the tropics and anomalous sinking over the subtropical ocean (Fig. 11a, b). The similarity between the coupled (Fig. 8e, f) and AGCM (Fig. 10a, b) experiments suggests that the inclusion of air-sea coupling does not have a substantial impact on changes in precipitation and large scale circulation in the tropical and subtropical Pacific in response to AA emission changes.

In response to AA induced SST anomalies, the changes in precipitation (Fig. 10c) and enhanced WNPSH (Fig. 10d) are similar to the response to both AA emission and AA induced SST changes (Fig. 10a, b). However, in response to changes in AA emissions without SST feedbacks there are no significant changes in the WNPSH (Fig. 10f) and the related stream function and vertical circulations over the western Pacific (Fig. 11e, f). Therefore, changes in precipitation, WNPSH, and local Hadley circulation over the tropical and subtropical Pacific in response to the changes in AA emissions in the coupled model are primarily due to AA induced SST feedbacks. This is consistent with Li et al., (2010), which suggests that the SST warming in the tropics is primary cause for the weakening of the EASM.

\section{Conclusions}

In observations there is a rapid increase of precipitation over southern China and a decrease over northern China across the mid-1990s, named as Southern-Flood-Northern-Drought (SFND) pattern. Corresponding to changes in precipitation is the weakened EASM, characterized by positive SLP anomalies over Asian continent and India, weaker southeasterly flow from the Indian Ocean and less moisture transport to northern China. In this study, we have performed a set of time-slice experiments using MetUM-GOML1 to quantify the roles of changes in: (1) All Forcing, the combined effects of greenhouse gas (GHG) and anthropogenic aerosols (AA) emissions, (2) GHG forcing and (3) AA emissions in generating the observed SFND pattern. Our principle results are as follows:

1. When forced by changes in All Forcing between two periods MetUM-GOML1 shows a dipole pattern of precipitation over China, which is similar to observed SFND pattern, and a weakened EASM. This similarity suggests that changes in the GHG and AA emissions contributed to the decadal changes of precipitation over East Asia across the mid-1990s, and the associated weakening in the EASM.

2. The forced increase in precipitation over East Asia is dominated by the changes in GHG forcing. The increased GHG enhances the Western North Pacific Subtropical High (WNPSH) and SLP over southern China decreases, which leads to enhanced southerly winds on the western boundary of WNPSH and increased moisture transport from the South China Sea. In addition, the GHG induced warming increases the moisture content in the atmosphere, leading to enhanced moisture transport and transport convergence over East Asia. There- 
(a)

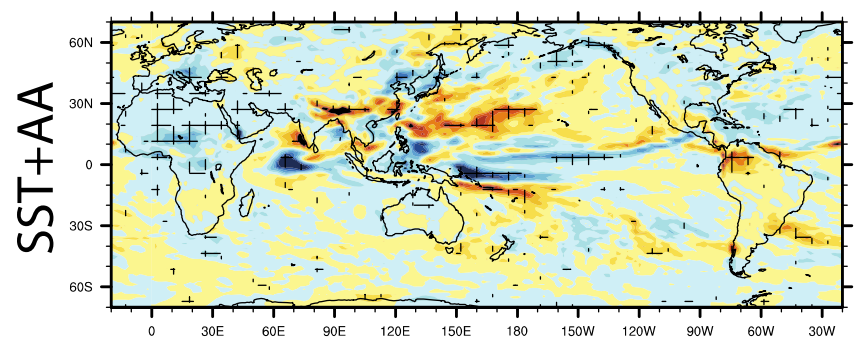

(c)

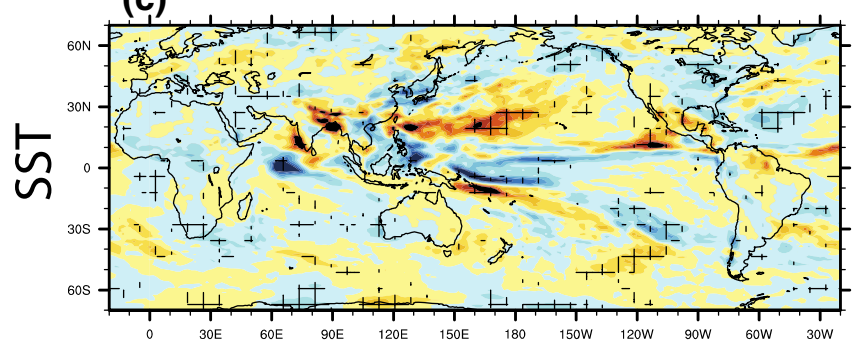

(e)

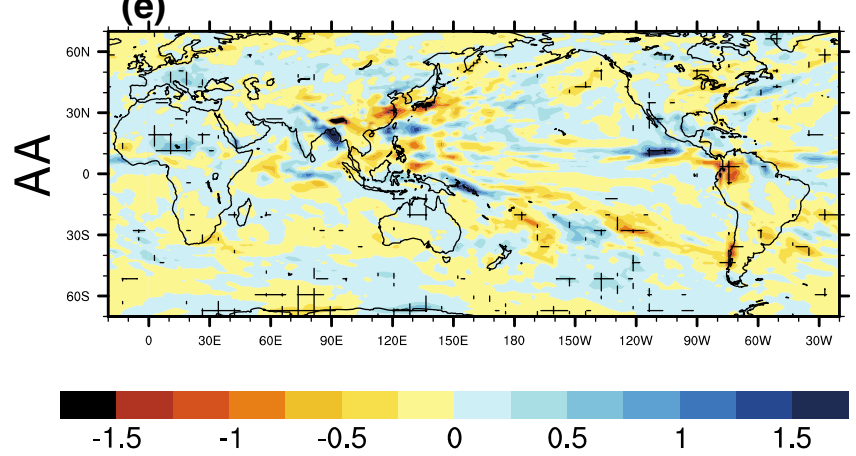

Fig. 10 Precipitation (mm/day) and SLP (hPa) difference between present day (ASST and ASA) and early period (AEP) AGCM experiments in JJA. In response to changes in both SST and AA forcing (ASA-AEP, top row), only SST forcing (ASST-AEP, middle row) and

fore, both the thermodynamic and dynamic processes are important in leading to more precipitation over East China.

3. The decrease in precipitation over northern China is dominated by the changes in AA forcing. The significant decrease in precipitation in response to AA changes is dominated by the dynamic effect related to AA induced circulation change. AA forcing changes lead to the increase of SLP around $20^{\circ} \mathrm{N}$, with the maximum over northern India and Western North Pacific, which corresponds to a weakening in EASM. Thus, less water vapor is transported to East Asia, corresponding to reduced precipitation.

4. The changes in SLP are one of the important factors in generating the SFND pattern. Over East Asia, the changes in SLP are related to the heterogeneous changes of surface air temperature. Changes in GHG

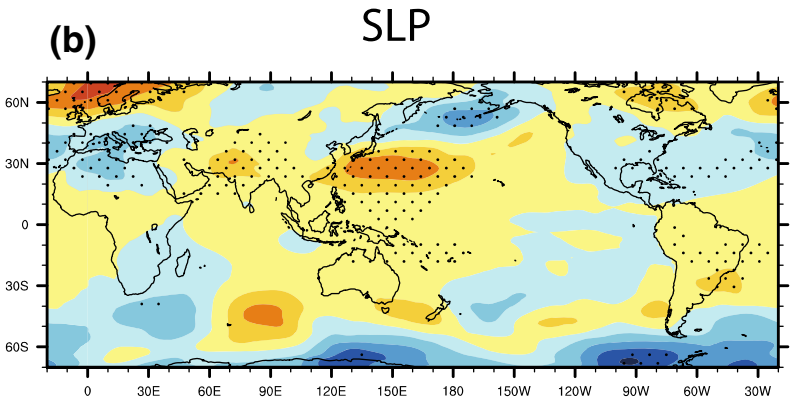

(d)

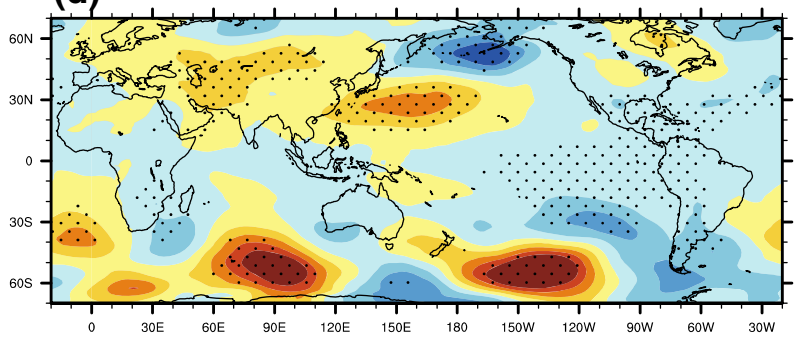

(f)

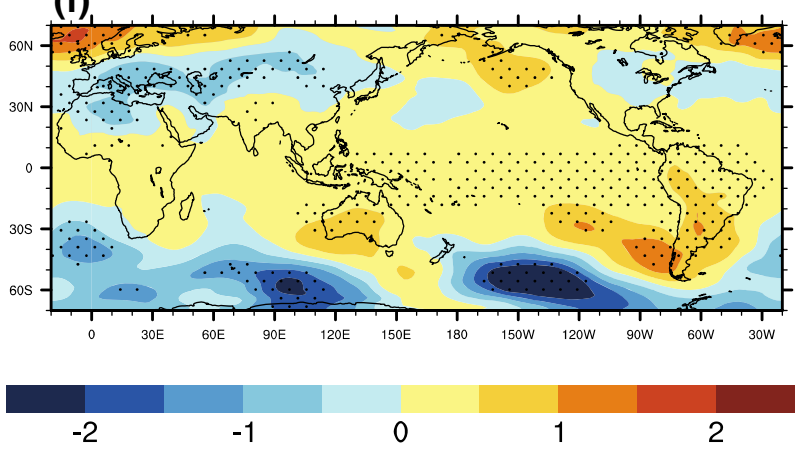

only AA forcing (ASA-ASST, right row). Grids and dots highlight regions where the changes are statistically significant at the $10 \%$ level using a two-tailed Student t-test

forcing lead to surface warming over the Asian continent, which is related to anomalous ascent and decreased SLP. Changes in AA forcing leads to surface cooling over northern India and southern China, which corresponds to anomalous sinking and increased SLP. Over the western Pacific, the changes in SLP are related to the heterogeneous changes of SST. Changes in GHG forcing are related to SST warming with the maximum in the equatorial ocean. In contrast, changes in AA forcing lead to a subtropical cooling, which makes the ITCZ shift southward. The changes in ITCZ in response to both changes in GHG and AA forcings enhances the sinking anomalies over subtropical latitudes, which enhance the WNPSH.

It should be noted that in this work the GHG forcing and AA forcing are taken as independent forcing factors. 


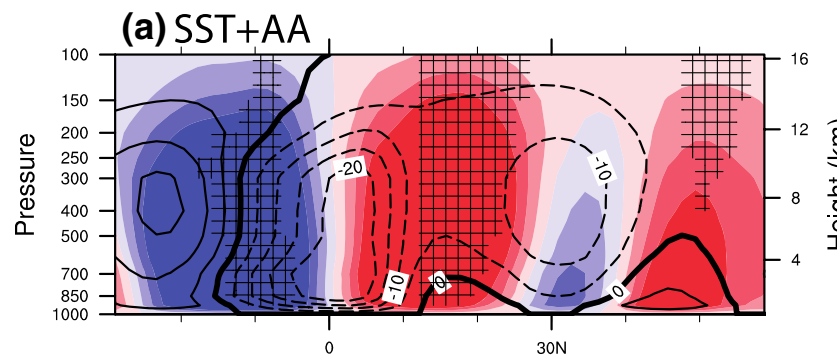

(c) SST

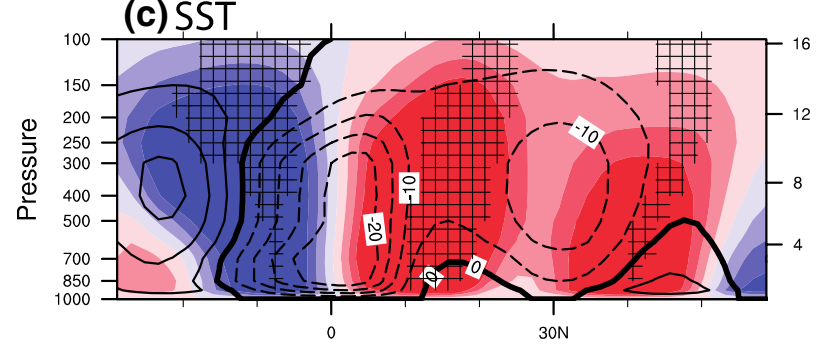

(e) AA

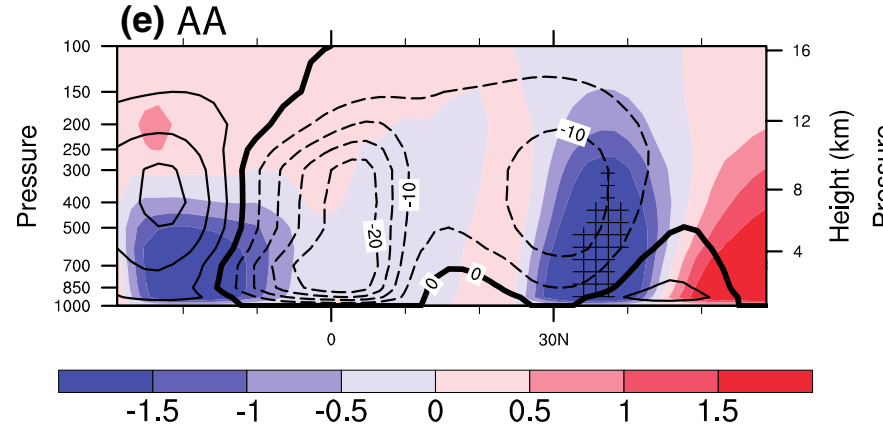

(b) $S S T+A A$

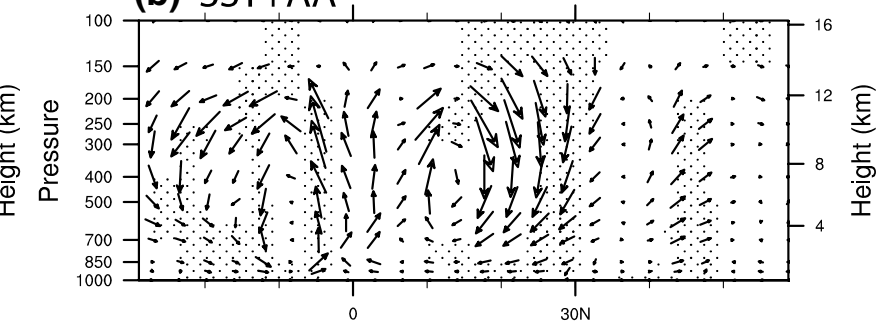

(d) SST

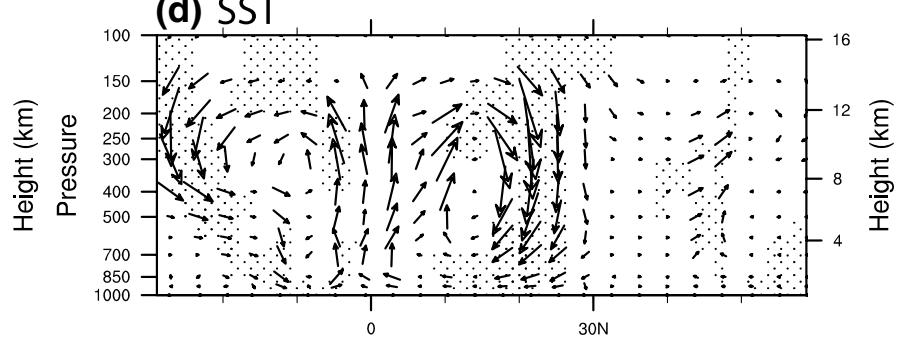

(f) AA

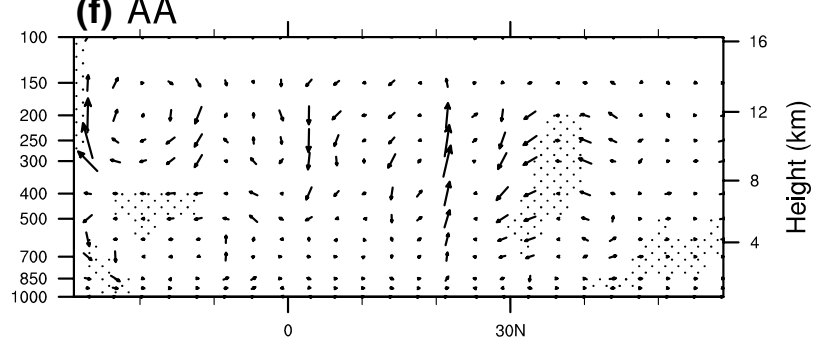

in SST and AA forcing (a, b), SST forcing (c, d) and AA forcing (e, f). Grids and dots highlight regions where the changes are statistically significant at the $10 \%$ level using a two-tailed Student t-test

c, e) and wind $\left(\mathrm{m} / \mathrm{s} \times 10^{-3}\right)$ anomalies $(\mathbf{b}, \mathbf{d}, \mathbf{f})$ over the Pacific $\left(30^{\circ} \mathrm{S}-60^{\circ} \mathrm{N}, 120^{\circ} \mathrm{E}-150^{\circ} \mathrm{W}\right)$. Dashed lines indicate the climate state of AEP experiment. Colours are the anomalies in response to changes

Previous studies (Feichter et al. 2004; Ming and Ramaswamy 2009; Shiogama et al. 2012) indicated a nonlinearity of responses to changes in different forcings (i.e., the response to the combined forcings is not necessarily equal to the sum of the responses to the individual forcings). In this study, we also noticed a nonlinearity of EASM changes in response to changes in GHG and AA emissions. However, detailed discussion of this nonlinearity is beyond the scope of this study.

This work also suggested that the change of local Hadley cell in response to different forcings is strongly related to the changes of SST pattern which has the maximum warming over equatorial Pacific and minimum warming over subtropical Pacific (Fig. 8d-f). Further studies are needed to understand the mechanisms through which the GHG and AA lead to the SST patterns.

Although the model appears to capture the SFND pattern, it is important to note that the results may be sensitive to the model or experimental design. For example, this work is based on the time-slice experiments forced by early

period (1964-1981) and present day (1994-2011) GHG and AA emission. Additionally, the oceanic component of the model used is a mixed-layer model, in which the ocean dynamic processes are not fully considered. Therefore, the simulated changes in SST and some other variables may not be the same as those in Coupled General Circulation Models (CGCMs) that include a fully dynamic 3D ocean. As Li and Ting (2017) revealed, while the thermodynamic response of Asia monsoon is robust across the CMIP5 models, there is a lack of consensus for the dynamic responses, possibly due to the multiple physical processes evolving on different time scales. Hence, in the future the results in this paper should be tested using different different models. Particularly, it will be useful to compare our results with other studies which considered the temporal evolution of the climate changes and also the responses of the oceanic general circulation.

Acknowledgements The authors would like to thank Laura Wilcox for helpful discussion and suggestions. This work is supported by UKChina Research \& Innovation Partnership Fund through the Met Office 
Climate Science for Service Partnership (CSSP) China as part of the Newton Fund. BD, JR, and RS are supported by the U.K. National Centre for Atmospheric Science-Climate (NCAS-Climate) at the University of Reading. The authors would also like to thank two anonymous reviewers for their constructive comments and suggestions on the paper.

Open Access This article is distributed under the terms of the Creative Commons Attribution 4.0 International License (http://creativeco mmons.org/licenses/by/4.0/), which permits unrestricted use, distribution, and reproduction in any medium, provided you give appropriate credit to the original author(s) and the source, provide a link to the Creative Commons license, and indicate if changes were made.

\section{References}

Arribas A, Glover M, Maidens A, Peterson K, Gordon M, MacLachlan C, Xavier P (2011) The GloSea4 ensemble prediction system for seasonal forecasting. Mon Weather Rev 139(6):1891-1910

Bollasina MA, Ming Y, Ramaswamy V (2011) Anthropogenic aerosols and the weakening of the South Asian summer monsoon. Science 334(6055):502-505

Chen H, Sun J (2017) Anthropogenic warming has caused hot droughts more frequently in China. J Hydrol 544:306-318

Chou C, Neelin JD, Chen CA, Tu JY (2009) Evaluating the "rich-getricher" mechanism in tropical precipitation change under global warming. J Clim 22(8):1982-2005

Dai A, Li H, Sun Y, Hong LC, Chou C, Zhou T (2013) The relative roles of upper and lower tropospheric thermal contrasts and tropical influences in driving Asian summer monsoons. J Geophys Res Atmos 118(13):7024-7045

Ding Y, Wang Z, Sun Y (2008) Inter-decadal variation of the summer precipitation in East China and its association with decreasing Asian summer monsoon. Part I: observed evidences. Int J Climatol 28(9):1139-1161

Ding Y, Sun Y, Wang Z, Zhu Y, Song Y (2009) Inter-decadal variation of the summer precipitation in China and its association with decreasing Asian summer monsoon Part II: possible causes. Int J Climatol 29(13):1926-1944

Dong B, Gregory JM, Sutton RT (2009) Understanding land-sea warming contrast in response to increasing greenhouse gases. Part I: transient adjustment. J Clim 22(11):3079-3097

Dong B, Sutton RT, Highwood EJ, Wilcox LJ (2016) Preferred response of the East Asian summer monsoon to local and nonlocal anthropogenic sulphur dioxide emissions. Clim Dyn 46(5-6):1733-1751

Dong B, Sutton RT, Shaffrey L, Klingaman NP (2017) Attribution of forced decadal climate change in coupled and uncoupled oceanatmosphere model experiments. J Clim 30(16):6203-6223

Feichter J, Roeckner E, Lohmann U, Liepert B (2004) Nonlinear aspects of the climate response to greenhouse gas and aerosol forcing. J Clim 17:2384-2398

Held IM, Soden BJ (2006) Robust responses of the hydrological cycle to global warming. J Clim 19(21):5686-5699

Hirons LC, Klingaman NP, Woolnough SJ (2015) MetUM-GOML: a near-globally coupled atmosphere-ocean-mixed-layer model. Geosci Model Dev 8:363-379

Jones $\mathrm{C}$ et al (2011) The HadGEM2-ES implementation of CMIP5 centennial simulations. Geophys Model Dev 4:543-570

Klingaman NP, Woolnough SJ, Weller H, Slingo JM (2011) The impact of finer-resolution air-sea coupling on the intraseasonal oscillation of the Indian monsoon. J Clim 24(10):2451-2468
Lamarque JF, Bond TC, Eyring V, Granier C, Heil A, Klimont Z et al (2010) Historical (1850-2000) gridded anthropogenic and biomass burning emissions of reactive gases and aerosols: methodology and application. Atmos Chem Phys 10(15):7017-7039

Lamarque JF, Kyle GP, Meinshausen M, Riahi K, Smith SJ, van Vuuren $\mathrm{DP}$ et al (2011) Global and regional evolution of short-lived radiatively-active gases and aerosols in the representative concentration pathways. Clim change 109(1-2):191

Lee SM, Jhun JG, Kwon M, Kim W (2008) Change in the western North Pacific summer monsoon circulation due to the $\mathrm{CO}_{2}$ increase in IPCC AR4 CGCMs. Asia Pac J Atmos Sci 44(4):351-368

Large WG, McWilliams JC, Doney SC (1994) Oceanic vertical mixing: A review and a model with a nonlocal boundary layer parameterization. Rev Geophys 32(4):363-403

Li X, Ting M (2017) Understanding the Asian summer monsoon response to greenhouse warming: the relative roles of direct radiative forcing and sea surface temperature change. Clim Dyn 49(7-8):2863-2880

Li H, Dai A, Zhou T, Lu J (2010) Responses of East Asian summer monsoon to historical SST and atmospheric forcing during 19502000. Clim Dyn 34(4):501-514

Li X, Ting M, Li C, Henderson N (2015) Mechanisms of Asian summer monsoon changes in response to anthropogenic forcing in CMIP5 models. J Clim 28(10):4107-4125

Ma S, Zhou T, Stone DA, Polson D, Dai A, Stott PA et al (2017) Detectable anthropogenic shift toward heavy precipitation over eastern China. J Clim 30(4):1381-1396

Ming Y, Ramaswamy V (2009) Nonlinear climate and hydrological responses to aerosol effects. J Clim 22:1329-1339

Ming Y, Ramaswamy V (2011) A model investigation of aerosolinduced changes in tropical circulation. J Clim 24(19):5125-5133

Penner JE, Andreae MO, Annegarn H, Barrie L, Feichter J, Hegg D, Pitari G (2001) Aerosols, their direct and indirect effects. Climate Change 2001: the scientific basis. Contribution of Working Group I to the third assessment report of the intergovernmental panel on climate change. Cambridge University Press, pp 289-348

Rayner NA, Parker DE, Horton EB, Folland CK, Alexander LV, Rowell DP et al (2003) Global analyses of sea surface temperature, sea ice, and night marine air temperature since the late nineteenth century. J Geophys Res Atmos 108(D14):1-37

Rotstayn LD, Lohmann U (2002) Tropical rainfall trends and the indirect aerosol effect. J Clim 15(15):2103-2116

Rotstayn LD, Penner JE (2001) Indirect aerosol forcing, quasi forcing, and climate response. J Clim 14(13):2960-2975

Shen C, Wang WC, Hao Z, Gong W (2008) Characteristics of anomalous precipitation events over eastern China during the past five centuries. Clim Dyn 31(4):463-476

Shiogama H, Stone DA, Nagashima T, Nozawa T, Emori S (2012) On the linear additivity of climate forcing-response relationships at global and continental scales Int. J Climatol 33:2542-2550

Smith DM, Murphy JM (2007) An objective ocean temperature and salinity analysis using covariances from a global climate model. J Geophys Res Oceans 112(C2):1-19

Song F, Zhou T, Qian Y (2014) Responses of East Asian summer monsoon to natural and anthropogenic forcings in the 17 latest CMIP5 models. Geophys Res Lett 41(2):596-603

Trenberth KE, Guillemot CJ (1995) Evaluation of the global atmospheric moisture budget as seen from analyses. J Clim 8(9):2255-2272

Valcke S, Caubel A, Declat D, Terray L (2003) OASIS3 ocean atmosphere sea ice soil user's guide. Prisim project report, 2

Vannière B, Guilyardi E, Madec G, Doblas-Reyes FJ, Woolnough S (2013) Using seasonal hindcasts to understand the origin of the 
equatorial cold tongue bias in CGCMs and its impact on ENSO. Clim Dyn 40(3-4):963-981

Vecchi GA, Soden BJ (2007) Global warming and the weakening of the tropical circulation. J Clim 20(17):4316-4340

Waliser DE, Murtugudde R, Lucas LE (2004) Indo-Pacific ocean response to atmospheric intraseasonal variability: 2 . Boreal summer and the Intraseasonal Oscillation. J Geophys Res Oceans 109(C3):1-26

Walters DN, Best MJ, Bushell AC, Copsey D, Edwards JM, Falloon PD, Roberts MJ (2011) The met office unified model global atmosphere 3.0/3.1 and JULES global land 3.0/3.1 configurations. Geosci Model Dev 4(4):919

Wang HJ (2001) The weakening of the Asian monsoon circulation after the end of 1970's. Adv Atmos Sci 18(3):376-386

Wang C (2004) A modeling study on the climate impacts of black carbon aerosols. J Geophys Res Atmos 109(D3):1-28

Wang C (2006) Direct radiative forcing of black carbon aerosols and tropical convective precipitation. AGU Fall Meeting Abstracts

Wang T, Otterå OH, Gao Y, Wang H (2012) The response of the North Pacific decadal variability to strong tropical volcanic eruptions. Clim Dyn 39(12):2917-2936
Wang T, Wang HJ, Otterå OH, Gao YQ, Suo LL, Furevik T, Yu L (2013) Anthropogenic agent implicated as a prime driver of shift in precipitation in eastern China in the late 1970s. Atmos Chem Phys 13(24): 12433

Wang B, Yim SY, Lee JY, Liu J, Ha KJ (2014) Future change of AsianAustralian monsoon under RCP 4.5 anthropogenic warming scenario. Clim Dyn 42(1-2):83-100

Williams KD, Jones A, Roberts DL, Senior CA, Woodage MJ (2001) The response of the climate system to the indirect effects of anthropogenic sulfate aerosol. Clim Dyn 17(11):845-856

Xie SP, Deser C, Vecchi GA, Ma J, Teng H, Wittenberg AT (2010) Global warming pattern formation: sea surface temperature and rainfall. J Clim 23(4):966-986

Xie X, Wang H, Liu X, Li J, Wang Z, Liu Y (2016) Distinct effects of anthropogenic aerosols on the East Asian summer monsoon between multidecadal strong and weak monsoon stages. J Geophys Res Atmos 121:7026-7040. https://doi.org/10.1002/2015J D024228

Zhang L, Wu P, Zhou T (2017) Aerosol forcing of extreme summer drought over North China. Environ Res Lett 12:034020. https:// doi.org/10.1088/1748-9326/aa5fb3 